\title{
Evaluating the diversity of the Feline Immunodeficiency Virus (FIV): a leopard perspective
}

\author{
Tanya J. Kerr ${ }^{1,2 *}(\mathbb{D})^{\S}$, Conrad Matthee ${ }^{3}(\mathbb{D})$, Sonja Matthee ${ }^{1}(\mathbb{D})$, \\ Danny Govender ${ }^{4,5}$ \& Susan Engelbrecht ${ }^{2,6 *}$ (DD) \\ ${ }^{1}$ Department of Conservation Ecology and Entomology, Faculty of AgriScience, \\ Stellenbosch University, Private Bag X1, Stellenbosch, 7602 South Africa \\ ${ }^{2}$ Division of Medical Virology, Department of Pathology, Faculty of Medicine and Health Sciences, \\ Stellenbosch University, Tygerberg Campus, P.O. Box 241, Cape Town, 8000 South Africa \\ ${ }^{3}$ Evolutionary Genomics Group, Department of Botany and Zoology, Faculty of Science, \\ Stellenbosch University, Private Bag X1, Stellenbosch, 7602 South Africa \\ ${ }^{4}$ Scientific Services, SANParks, Private Bag X402, Skukuza, 1350 South Africa \\ ${ }^{5}$ Department of Paraclinical Sciences, Faculty of Veterinary Science, \\ University of Pretoria, Private Bag X04, Onderstepoort, 0110 South Africa \\ ${ }^{6}$ National Health Laboratory Service (NHLS), Tygerberg Coastal, Cape Town, 8000 South Africa \\ Received 14 November 2016. To authors for revision 16 February 2017. Accepted 22 March 2017
}

\begin{abstract}
To obtain more insights into the prevalence and diversity of species-specific Feline Immunodeficiency Virus (FIV) strains in naturally occurring felid species, 26 leopards (Panthera pardus) from the Kruger National Park (KNP), South Africa, were sampled. Prevalence was determined using a PCR protocol designed to target a $577 \mathrm{bp}$ fragment in the pol-RT gene. Overall prevalence of $\mathrm{FIV}_{\mathrm{Ppa}}$ was estimated at $73 \%$, with no difference in prevalence between male and female leopards. Consistent with previous FIV studies on other felid species, prevalence appears to increase with age (adult $=84 \%$; subadult $=43 \%$ ). Phylogenetic analyses of these novel sequences were conducted against a revised FIV pol-RT species-specific reference dataset using both Bayesian and maximum likelihood methods. Within FIV $\mathrm{ppa}_{\mathrm{p}}$ two distinct evolutionary groupings are present, which suggests the possibility of geographic variation within $\mathrm{FIV}_{\mathrm{Ppa}}$ and the possibility of distinct subtypes, similar to what has been found in lions (Panthera leo) and domestic cats (Felis catus). The larger FIV dataset provides new insights into the epidemiology of this under-studied FIV strain and with such high prevalence rates, further studies should focus on immunological and clinical consequences of FIV in wild felids.
\end{abstract}

Key words: FIV diversity, FIV reference dataset, geographic variation, Kruger National Park, Panthera pardus, FIV pol-RT.

\section{INTRODUCTION}

Lentiviruses (Retroviridae) such as the well-known Human Immunodeficiency Virus (HIV) are not unique to humans and have been isolated from a number of mammalian taxa (Miller, Cairns, Bridges \& Sarver, 2000). For example, two well-studied lentiviruses in animals include the primate associated Simian Immunodeficiency Virus (SIV) and the feline associated Feline Immunodeficiency Virus (FIV). HIV in humans represents a recent cross-species transmission of SIV from

\begin{tabular}{|c|c|}
\hline $\begin{array}{l}\text { *To whon } \\
\text { E-mail: } t\end{array}$ & $\begin{array}{l}\text { m correspondence should be addressed. } \\
\text { tjkerr@sun.ac.za/susanen@sun.ac.za }\end{array}$ \\
\hline SORCID: & $\begin{array}{l}\text { T.J.K. } 0000-0002-3890-4959 \\
\text { C.M. } 0000-0002-6836-069 X \\
\text { S.M. } 0000-0001-7289-6262 \\
\text { S.E. } 0000-0002-1318-5994 \\
. \square\end{array}$ \\
\hline
\end{tabular}

non-human primates, and apart from SIV, FIV represents the only other well-studied natural animal model to explain the evolution of Immunodeficiency Viruses in mammals. In fact, HIV, SIV and FIV are structurally, genomically and seemingly pathogenically similar (Pedersen, Yamamoto, Ishida \& Hansen, 1989; Bendinelli et al., 1995; Miller et al., 2000; O’Brien, Troyer, Roelke, Marker \& Pecon-Slattery, 2006).

FIV (previously feline T-lymphotropic lentivirus) was first described in the domestic cat (Felis catus) nearly 30 years ago (Pedersen et al., 1989) and has since been detected in several nondomestic felids (Olmsted et al., 1992; Brown, Miththapala \& O'Brien, 1993; Troyer et al., 2005). Within the family Felidae (comprising 38 species), 19 species have been identified as sero-reactive to 
FIV, and infection has been confirmed in 11 species using PCR (Troyer et al., 2005; Pecon-Slattery, Troyer, Johnson \& O'Brien, 2008b). Lentiviruses infecting feline species are related (VandeWoude et al., 1997; Troyer et al., 2005) and in most instances FIV is species-specific (VandeWoude \& Apetrei, 2006). Unique FIV lineages have been described in the domestic cat $\left(\mathrm{FIV}_{\mathrm{Fca}}\right)$ (Olmsted et al., 1989a; Olmsted, Hirsch, Purcell \& Johnson, 1989b), African lion (Panthera leo- FIV $_{\mathrm{Pl}}$ ) (Brown, Yuhki, Packer \& O'Brien, 1994; Troyer et al., 2005), puma (Puma concolor - FIV $_{\mathrm{Pco}}$ ) (Olmsted et al., 1992; Carpenter et al., 1996), Pallas cat (Otocolobus manul - FIV Oma $_{\text {) }}$ (Troyer et al., 2005; Brown et al., 2010), bobcat (Lynx rufus - FIV (Franklin et al., 2007; Lee et al., 2012), cheetah (Acinonyx jubatus - FIV $_{\text {Aju }}$ ) (Troyer et al., 2005), leopard (Panthera pardus - $\mathrm{FIV}_{\mathrm{Ppa}}$ ) (Carpenter et al., 1996; Troyer et al., 2005), ocelot (Leopardus pardalis - FIV $_{\mathrm{Lpa}}$ ) (Troyer et al., 2005), jaguarundi (Puma yagouaroundi-FIV formerly Herpailurus yagouaroundi - FIV Hya $_{\text {) }}$ (Troyer et al., 2005; Johnson et al., 2006), snow leopard (Panthera unciaFIV $_{\text {Pun }}$ ) (Troyer et al., 2005) and spotted hyaena (Crocuta crocuta - FIV Crr $_{\text {) }}$ ) within the family Hyaenidae (Troyer et al., 2005). The diversity among FIV strains within most of these host species is not that well documented, and more research is needed to answer questions regarding the presence and spatial distribution of FIV strains and subtypes. For those felids that have been more extensively studied, there is sufficient evidence to support large scale variation within species-specific strains of FIV. For example, five different monophyletic subtypes were detected

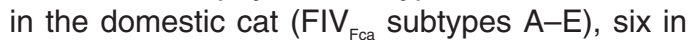

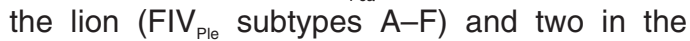
puma ( IV $_{\mathrm{P}_{\mathrm{co}}}$ subtypes $\mathrm{A}$ and $\mathrm{B}$ ) as reviewed by VandeWoude and Apetrei (2006) and (O'Brien et al., 2012). In some instances, these subtypes are also geographically confined (Troyer et al., 2005; Antunes et al., 2008).

Leopards are the largest of the spotted felids found in Africa (Skinner \& Chimimba, 2005) and have a distribution that extends beyond that of many other felid species (Skinner \& Chimimba, 2005; Henschel et al., 2008). Like most members of the Felidae, leopards are solitary and are generally only seen together when males and females are mating or if a female is accompanied by subadults or cubs (Skinner \& Chimimba, 2005; Macdonald \& Loveridge, 2010). The large geographic but intermittent range of leopards across Africa leads to predictions that some geographic variation may be present in FIV Ppa. In addition, the solitary nature of leopards may limit contact between individuals, and the prevalence of FIV in leopards is therefore predicted to be lower than the prevalence of FIV in more social species such as lions.

Knowing the prevalence and diversity of FIV $_{\mathrm{Ppa}}$ in leopards is also important from a conservation perspective. The global leopard population is declining (Henschel et al., 2008; Stein et al., 2016) leading to the amendment of their conservation status from Near Threatened (Henschel et al., 2008) to Vulnerable (Stein et al., 2016) by the International Union for the Conservation of Nature (IUCN). Although the pathogenic effects of FIV in domestic cats have been more extensively studied, the pathogenic potential of the virus in wild felids is less well known (Brown et al., 1994; HofmannLehmann et al., 1996; Pecon-Slattery et al., 2008a; Adams et al., 2009). In fact, baseline data for FIV in leopards is lagging behind as exemplified by the availability of only five FIV $_{\mathrm{Ppa}}$ pol-RT sequences in GenBank (Carpenter et al., 1996; Troyer et al., 2005).

This study aimed to extend the current knowledge on FIV diversity in wild felid species, and particularly in leopards. By screening free-ranging leopards occurring in the Kruger National Park (KNP), one of the largest protected areas in southern Africa, we aimed to provide new insights into the prevalence and diversity of FIV $_{\mathrm{Ppa}}$. To place the newly documented findings in perspective with what is known for FIV in felids, we compare the prevalence of FIV to other felid species and provide a phylogenetic analysis of FIV using all previously published FIV sequences available from GenBank. Since no current predefined reference dataset exists for FIV, such as the Los Alamos HIV Database (http://www.hiv.lanl.gov), we proposed an updated FIV pol-RT reference dataset to be used in future studies (also see Troyer et al. (2005)). The FIV database represents a backbone where all duplicated sequences with different accession numbers were removed and it contains no missing data. For future referencing and expansion of the database, contributing authors and their associated studies were cited for each sequence and the sequence metadata was also summarized in tabular format.

\section{MATERIALS AND METHODS}

\section{Sample collection}

Between 2007 and 2013, 26 blood samples 


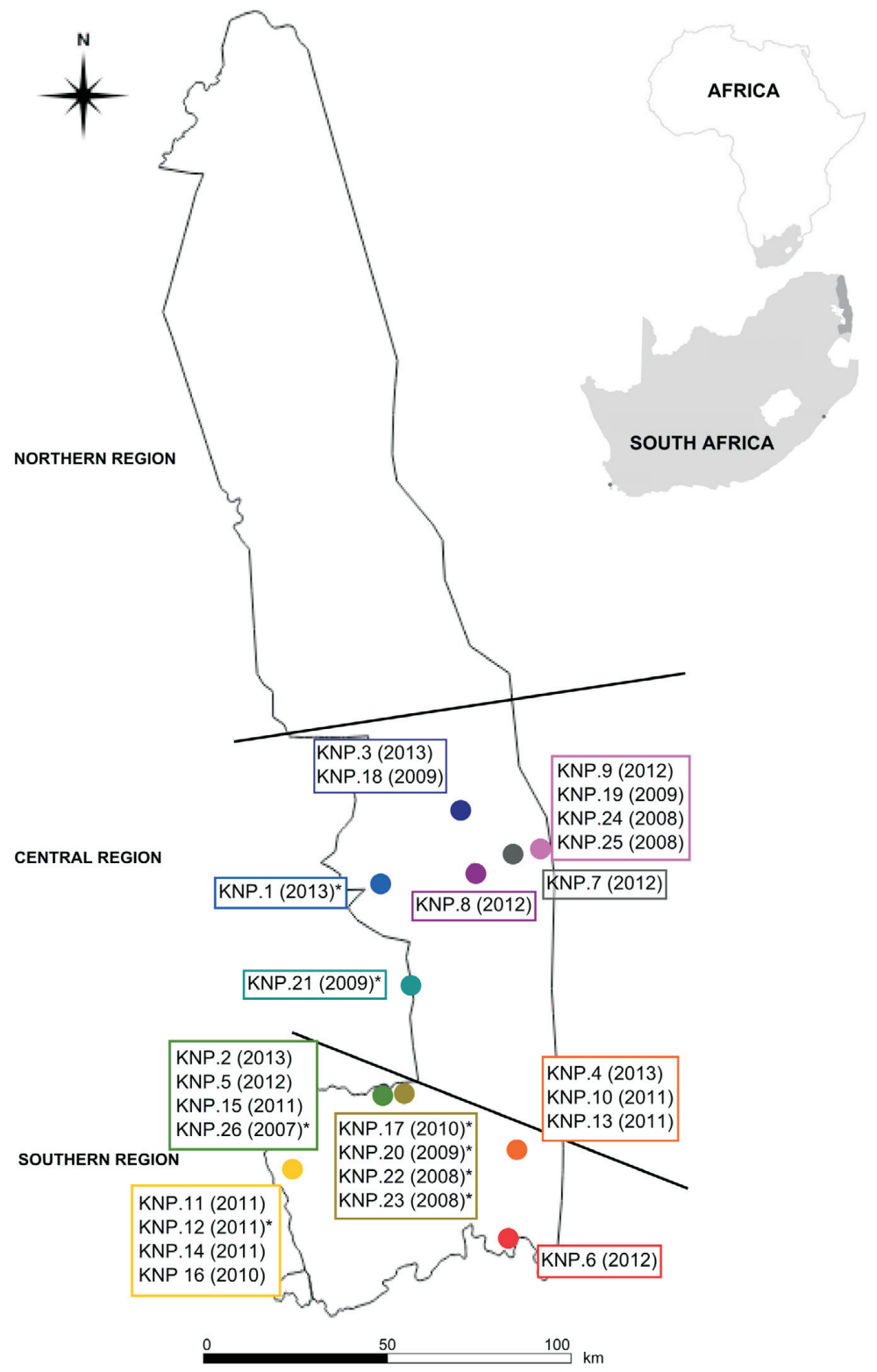

Fig. 1. Map of Kruger National Park indicating approximate sampling locations of the 26 leopards included in this study. Year of sampling is included in brackets. GPS data (exact sample location) was not available for all individuals. For these individuals sample location was inferred based on capture location (Table 1). These individuals are designated using an '*'. Insets represent the position of South Africa in Africa and the darkly shaded area within South Africa represent the scaled to size position of the Kruger National Park.

(preserved in EDTA) were opportunistically collected from free-ranging leopards that were livetrapped in the KNP, South Africa (Fig. 1; Table 1). Ethical approval for the procedure was provided by the South African National Parks (SANParks) Animal Use and Care Committee (Protocol \#: 589MAPNW). All procedures including the plan- ning and capture of leopards were undertaken by the Scientific Services and Veterinary Wildlife Services of SANParks, using methods ratified by the organization's Animal Use and Care Committee (SANParks, 2015). All blood samples were stored at $-80^{\circ} \mathrm{C}$ in the Skukuza Biobank (SANParks, South Africa). Samples were transferred from the 
Table 1. Demographic information and FIV status for the 26 free-ranging leopards sampled in Kruger National Park, South Africa.

\begin{tabular}{|c|c|c|c|c|c|c|}
\hline ID \# & Sex & Age & Sample year & FIV PCR & Location & Status \\
\hline Ppa-KNP.1 & M & Adult & 2013 & + & Kingfisherspruit & Wild \\
\hline Ppa-KNP.2 & $M$ & Adult & 2013 & + & Mbabala Drainage, Skukuza & Wild \\
\hline Ppa-KNP.3 & $\mathrm{F}$ & Subadult & 2013 & + & Satara & Wild \\
\hline Ppa-KNP.4 & M & Adult & 2013 & - & Lower Sabie & Wild \\
\hline Ppa-KNP.5 & $\mathrm{F}$ & Adult & 2012 & + & Tinga, Skukuza & Wild \\
\hline Ppa-KNP.6 & $\mathrm{F}$ & Adult & 2012 & + & Crocodile Bridge & Wild \\
\hline Ppa-KNP.7 & $\mathrm{F}$ & Subadult & 2012 & - & Shishangane, Satara & Wild \\
\hline Ppa-KNP.8 & $\mathrm{F}$ & Subadult & 2012 & + & Satara & Wild \\
\hline Ppa-KNP.9 & $\mathrm{F}$ & Subadult & 2012 & - & Singita, Nwanetsi & Wild \\
\hline Ppa-KNP.10 & M & Adult & 2011 & + & Lower Sabie & Wild \\
\hline Ppa-KNP.11 & M & Adult & 2011 & + & Rest Camp, Pretoriuskop & Wild \\
\hline Ppa-KNP.12 & $\mathrm{F}$ & Adult & 2011 & + & Bomas, Pretoriuskop & Wild \\
\hline Ppa-KNP.13 & $\mathrm{F}$ & Adult & 2011 & + & Rest Camp, Lower Sabie & Wild \\
\hline Ppa-KNP.14 & M & Subadult & 2011 & + & Pretoriuskop & Wild \\
\hline Ppa-KNP.15 & $\mathrm{F}$ & Adult & 2011 & + & TingaNarina Lodge, Skukuza & Wild \\
\hline Ppa-KNP.16 & $\mathrm{F}$ & Adult & 2010 & + & Pretoriuskop & Wild \\
\hline Ppa-KNP.17 & M & Adult & 2010 & + & Skukuza & Wild \\
\hline Ppa-KNP.18 & M & Adult & 2009 & - & Satara & Wild \\
\hline Ppa-KNP.19 & M & Adult & 2009 & + & Singita, Nwanetsi & Wild \\
\hline Ppa-KNP.20 & M & Adult & 2009 & + & Skukuza & Wild \\
\hline Ppa-KNP.21 & M & Adult & 2009 & + & Mala Game Reserve & Wild \\
\hline Ppa-KNP.22 & M & Subadult & 2008 & - & State Vet Bomas, Skukuza & Wild \\
\hline Ppa-KNP.23 & $\mathrm{F}$ & Subadult & 2008 & - & Skukuza & Wild \\
\hline Ppa-KNP.24 & M & Adult & 2008 & - & Singita Lebombo, Nwanetsi & Wild \\
\hline Ppa-KNP.25 & M & Adult & 2008 & + & Singita, Nwanetsi & Wild \\
\hline Ppa-KNP.26 & M & Adult & 2007 & + & Sabie Sands Game Reserve & Wild \\
\hline
\end{tabular}

Leopard identification number (ID \#); female (F); male (M); adult (>4 years); subadult (<4 years); PCR positive (+); PCR negative (-);

Location (KNP section/area where leopards were sampled).

Biobank and stored at $-20^{\circ} \mathrm{C}$ at the Division of Medical Virology, Stellenbosch University, prior to analysis.

\section{PCR amplification of proviral DNA}

Proviral DNA was automatically extracted from EDTA blood samples using a QIAGEN Blood Mini Kit and the QIACube (Qiagen, Hilden, Germany). Prior to PCR the DNA concentration $(n g / \mu l)$ for each proviral DNA extraction was determined using the NanoDrop ND-1000 Spectrophotometer (NanoDrop Technologies Inc., Wilmington, DE, U.S.A.). Nested PCR was performed using primers designed by Troyer et al. (2005) to target the conserved pol-RT region (577 bp) of the FIV $_{\text {Ppa }}$ genome. All oligonucleotide primers were synthesized by Integrated DNA Technologies (IDT Inc., Coralville, lowa, U.S.A.). First-round PCR was performed using $5 \mu \mathrm{l}$ of extracted DNA (DNA concentration range $3.49-39.06 \mathrm{ng} / \mu \mathrm{l})$ in a $50 \mu$ reaction with a final concentration of $1 \times \mathrm{GoTaq}^{\circledast}$ Flexi Buffer, $2 \mathrm{mM} \mathrm{MgCl}, 0.2 \mathrm{mM}$ concentrations of dNTPs, $0.4 \mu \mathrm{M}$ concentration of each primer, and 2.5 units of $\mathrm{GoTaq}^{\oplus}$ DNA polymerase (Promega, Madison, WI, U.S.A.). The first round of PCR involved the pre-nested $\mathrm{P} 1 \mathrm{~F}$ and $\mathrm{P} 2 \mathrm{R}$ primers and the cycle protocol on a GeneAmp ${ }^{\oplus}$ PCR System 9700 thermal cycler (Applied Biosystems, Carlsbad, CA, U.S.A.) was $2 \mathrm{~min}$ at $94^{\circ} \mathrm{C}, 40$ cycles of $20 \mathrm{~s}$ at $94^{\circ} \mathrm{C}, 30 \mathrm{~s}$ at $45^{\circ} \mathrm{C}$, and $45 \mathrm{~s}$ at $68^{\circ} \mathrm{C}$, followed by a final extension of $5 \mathrm{~min}$ at $68^{\circ} \mathrm{C}$. The second round of PCR was performed using $1 \mu \mathrm{l}$ of pre-nested PCR product with the nested primers $\mathrm{P} 2 \mathrm{~F}$ and $\mathrm{P} 1 \mathrm{R}$, and a cycle protocol of 2 min at $94^{\circ} \mathrm{C}, 30$ cycles of $20 \mathrm{~s}$ at $94^{\circ} \mathrm{C}, 30 \mathrm{~s}$ at $45^{\circ} \mathrm{C}$ and $45 \mathrm{~s}$ at $68^{\circ} \mathrm{C}$, followed by a final extension of $5 \mathrm{~min}$ at $68^{\circ} \mathrm{C}$. Negative controls were run alongside all $\mathrm{PCR}$ reactions to ensure that reagents were not contaminated during PCR. Agarose gel electrophoresis was performed on second-round 
PCR products to confirm amplification of nucleic acid fragments.

The representative second-round PCR products were purified using the Wizard $^{\circledR}$ SV Gel and PCR Clean-Up System (Promega, Madison, WI, U.S.A.) according to the manufacturer's instructions, and subsequently sequenced using the BigDye ${ }^{\circledR}$ Terminator v3.1 Cycle Sequencing Kit and standard procedures (Applied Biosystems, Carlsbad, CA, U.S.A.). Sequencing was undertaken in both the forward and reverse direction. Sequenced products were purified using BigDye ${ }^{\circledR}$ XTerminator Purification Kit (Applied Biosystems, Carlsbad, CA, U.S.A.) and analysed on the 3130xl Genetic Analyser (Applied Biosystems, Carlsbad, CA, U.S.A.). Sequencher ${ }^{\circledast}$ Version 5.0 (Gene Codes Corporation, Ann Arbor, MI, U.S.A.) was used to edit and align the contigs. Sequences were authenticated using the National Centre for Biotechnology Information Basic Local Alignment Search Tool (BLAST) software program (Altschul, Gish, Miller, Myers \& Lipman, 1990). Prior to phylogenetic analysis, multiple sequence alignment was undertaken using ClustalX Version 2.1 (Larkin et al., 2007). Sequence alignment was also optimized by using Codon Alignment Version 2.1.0 (http://www.hiv.lanl.gov) and manual adjustment.

\section{Phylogenetic analysis}

To place the diversity of newly generated FIV $_{\mathrm{Ppa}}$ sequence data in context with the existing knowledge on FIV in all felid species, a pol-RT reference dataset was generated (Supporting Text; Fig. S1; Table S1 - Supplementary Material). All sequences that met the minimum requirements as outlined in the supplementary materials were phylogenetically analysed using the Maximum Likelihood method implemented in MEGA Version 6 (Tamura, Stecher, Peterson, Filipski \& Kumar, 2013). To find the most suitable evolutionary model for phylogenetic inference, Model Selection (ML) within MEGA was used together with the Bayesian Information Criterion (BIC), (Nei \& Kumar, 2000). Bootstrap analysis included 1000 iterations. In addition, Bayesian posterior probabilities were determined using Markov Chain Monte Carlo methods in MrBayes Version 3.2 (Huelsenbeck \& Ronquist, 2001). The initial tree was random, and trees were sampled every 100 generations from a total of one million generations. Burn-in value corresponds to $25 \%$ of samples. To determine possible geographic structure among novel FIV $_{\text {ppa }}$ sequences, we repeated the above analyses including all $19 \mathrm{FIV}_{\mathrm{Ppa}}$ sequences obtained in the present study. Average sequence divergence and diversity values were derived from MEGA Version 6 using the optimal model of sequence evolution. Sequences were partitioned into distinct species-specific groups and then analysed to estimate the average evolutionary divergence and diversity together with the standard error for each.

\section{RESULTS}

\section{Prevalence of FIV in leopards}

Of the 26 leopard samples tested, PCR returned 19 positive samples resulting in an overall prevalence of $73 \%$. Both male $(n=15)$ and female $(n=11)$ leopards showed an estimated prevalence of $73 \%$. The prevalence of FIV in adult leopards (>4 years) was much higher $(84 \% ; n=19)$ than the prevalence of FIV in subadult individuals ( $<4$ years) $(43 \% ; n=7)$. Reliable FIV pol-RT sequences of over $500 \mathrm{bp}$ in length were obtained from all positive samples, and these $19 \mathrm{FIV}_{\mathrm{Ppa}}$ sequences were deposited in GenBank under accession numbers KU705335-KU705353.

\section{Phylogenetic analysis and sequence diversity of FIV pol-RT sequences}

For the FIV pol-RT reference dataset the data was trimmed at the ends to exclude all missing data. The phylogenetic analyses incorporated first a rooted approach using the FIV $_{\text {coo }}$ strain (Genbank accession numbers AY878196-AY878200 (Troyer et al., 2005)) and since rooting in FIV is variable and thus problematic (see Carpenter et al. (1996); Troyer et al. (2005); Franklin et al. (2007) and Antunes et al. (2008)), we also employed midpoint rooting. The rooted phylogeny was based on 83 sequences comprising $320 \mathrm{bp}$ in length and the final alignment of the midpoint rooted tree comprised 78 sequences of $369 \mathrm{bp}$ in length. Both the rooted and unrooted trees resulted in similar overall tree topologies (see also Franklin et al. (2007)). To prevent duplication in presentation, we only present the analyses based on midpoint rooting. The BIC score supported the $\mathrm{GTR}+\mathrm{G}+\mathrm{l}$ as the best fit model for the midpoint rooted phylogeny. For the expanded dataset, which was also midpoint rooted (an additional 14 closely related leopard sequences were included to test for phylogeographic structure) the optimal model of evolution was $\mathrm{T} 92+\mathrm{G}+\mathrm{l}$. In both analyses all $\mathrm{FIV}_{\mathrm{Ppa}}$ sequences obtained from the KNP sampling site were monophyletic with significant posterior prob- 
ability ( $\geq 95 \%$ ) and strong bootstrap support (ML Bootstrap $=92$, Fig. 2; and ML Bootstrap $=99$, Fig. 3). However, the monophyly of all FIV $_{\mathrm{Ppa}}$ sequences, was never retrieved in our analyses, since the monophyletic KNP clade is nested within a second clade comprising FIV from leopard, cheetah and Pallas cat (ML Bootstrap = 95; Fig. 2 and ML Bootstrap = 92; Fig. 3). In the present study, at least two distinct monophyletic lineages of FIV $_{\mathrm{Ppa}}$ are evident (Fig. 2; Fig. 3) albeit one of them with low bootstrap support (ML Bootstrap $<70$ ). These two lineages represent a common KNP Group ( $n=20$; inclusive of the previously published KNP sequence (Carpenter et al., 1996)) and a group derived from leopards of unknown geographic origin $(n=4)$. Within the KNP group there does not appear to be any significant geographic structure related to the sampling location of the individual leopards and their associated viral sequences (Fig. 1; Fig. 3).

The average sequence divergence for all sequence pairs in the FIV pol-RT reference dataset shows a mean value of $40.7 \pm 4.2 \%$ for FIV pol-RT. Even though the imbalance in sample sizes and limited geographic sampling can bias the comparisons between and within host species, it is interesting to note that with the data at hand the estimation of the sequence diversity based on the FIV pol-RT region for each species-specific group (where at least three or more sequences allowed for inclusion in the analysis) range from $7.6 \pm 1.8 \%$ in $\mathrm{FIV}_{\text {Oma }}$ to a high of $35.4 \pm 3.8 \%$ in FIV $_{\mathrm{Pco}}$ (Fig. 4). Analysis of divergence between each of the species-specific groups based on the FIV pol-RT region ranged from a low of $13.5 \pm 1.9 \%$ between $\mathrm{FIV}_{\mathrm{Ppa}}$ and $\mathrm{FIV}_{\mathrm{Aju}}$ to a high of $68.7 \pm 11.3 \%$ between FIV $_{\mathrm{Fca}}$ and FIV $_{\mathrm{Pun}}$ (Fig. 4). The genetic diversity of $7.9 \pm 1.1 \%$ for the currently sampled FIV $_{\mathrm{Ppa}}$ is thus towards the lower end of the spectrum (genetic diversity for the KNP group is $4.1 \pm 0.7 \%$ while it is $10.9 \pm 2.3 \%$ for the sequences on GenBank with an unknown geographic origin). Interestingly, the genetic divergence between the two leopard clades detected in our analyses is $14.3 \pm 3.8 \%$, and is also lower than the genetic divergences between the six $\mathrm{FIV}_{\mathrm{Ple}}$ subtypes which range from as low as $18.8 \pm 2.7 \%$ for $F_{\text {Ple }}$ subtype $B$ and $F$ to as high as $45.0 \pm 7.0 \%$ for FIV $_{\text {Ple }}$ subtype $C$ and $D$ (Fig. 4). It is also lower than the genetic divergence of $45.1 \pm 5.5 \%$ for the two FIV $_{\text {Pco }}$ subtypes (Fig. 4).

\section{DISCUSSION}

\section{Prevalence of FIV in leopards}

To date, a limited number of FIV pol-RT sequences have been available for leopards $(n=5)$. Here we provide sequence data for 19 new isolates and report a FIV $_{\mathrm{Ppa}}$ prevalence of $73 \%$ for the KNP leopard population. The PCR-detected prevalence is similar to the seroprevalence of $71 \%$ reported by Brown et al. (1993) for free-ranging leopards in KNP. These estimates are however considerably higher than the seroprevalence of $17 \%$ reported by Osofsky, Hirsch, Zuckerman \& Hardy (1996) for leopards from Botswana and the seroprevalence of between 26 and $46 \%$ reported by Troyer et al. (2005) for leopards from across Africa. The congruence between the seroprevalence and PCR detected prevalence of FIV $_{\mathrm{Ppa}}$ in KNP leopards is remarkable since a direct comparison between these methods is problematic. One of the limitations of using only PCR to estimate prevalence is that individuals which have a viral load below the detectable limit of a particular PCR may be missed (Troyer et al., 2004). Serological testing, on the other hand, has not been optimized for all wild felid species and the level of accuracy for this method has also been questioned (Troyer et al., 2005). Making accurate prevalence predictions is thus not only reliant on large samples sizes (Biau, Kerneis \& Porcher, 2008) but is dependent on sensitive and specific tests. To make a firm conclusion on the prevalence of $\mathrm{FIV}_{\mathrm{Ppa}}$ in leopards, a much bigger sampling effort over a larger geographic area would be required. The latter is needed since prevalence has also been shown to vary substan-

Fig. 2. Bayesian tree of 78 FIV pol-RT sequences (369 bp) isolated from the 10 felid species included in the proposed FIV pol-RT reference dataset. Posterior probabilities $\geq 0.95$ are indicated with ' $\bullet$ '. ML Bootstrap values above $70 \%$ (1000 iterations) are also indicated where found. The tree is midpoint rooted. Each sequence is designated by a unique sequence name comprising of GenBank accession number, virus abbreviation, felid species from which sample was collected, individual sample ID, FIV subtype where available, and country of origin (Table S1 - Supplementary Material). Sequences isolated from captive/wild-born captive animals are designated by ' $\star$ ', all other sequences were isolated from wild animals. Sequences are colour coded according to the host species from which

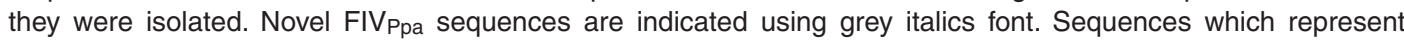
cross-species transmissions in captive settings are indicated with black italics font and shaded ' $\bullet$ '. 


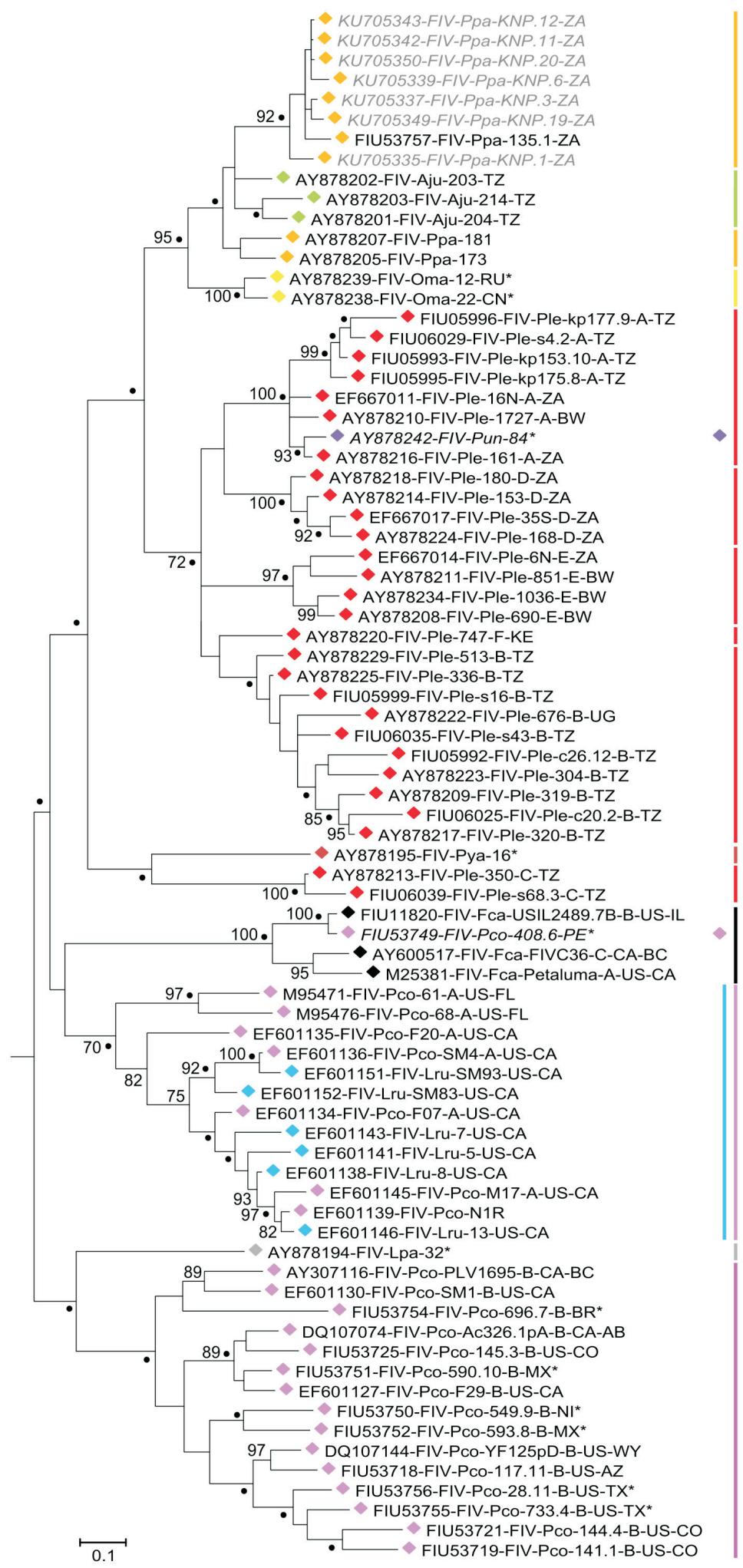

FIVPpa (Leopard) - South Africa

FIVAju (Cheetah) - Tanzania

FIVPpa (Leopard) - Unknown Provenance

FIVoma (Pallas Cat) - Asia

FIVPle A (Lion) - Tanzania, Botswana, South Africa

FIVPun (Snow Leopard)

FIVPle D (Lion) - South Africa

FIVPle E (Lion) - Botswana \& South Africa

FIVPle F (Lion) - Kenya

FIVPle B (Lion) - Tanzania \& Uganda

FIVPya (Jaguarundi)

FIVPle C (Lion) - Tanzania

FIVPco (Puma)

FIVFca (Domestic Cat) - North America

FIVLru (Bobcat) \& FIVPco A (Puma) North America

FIVLpa (Ocelot)

FIVPco B (Puma) - North \& South America 
Kerr et al.: Diversity of Feline Immunodeficiency Virus in leopards

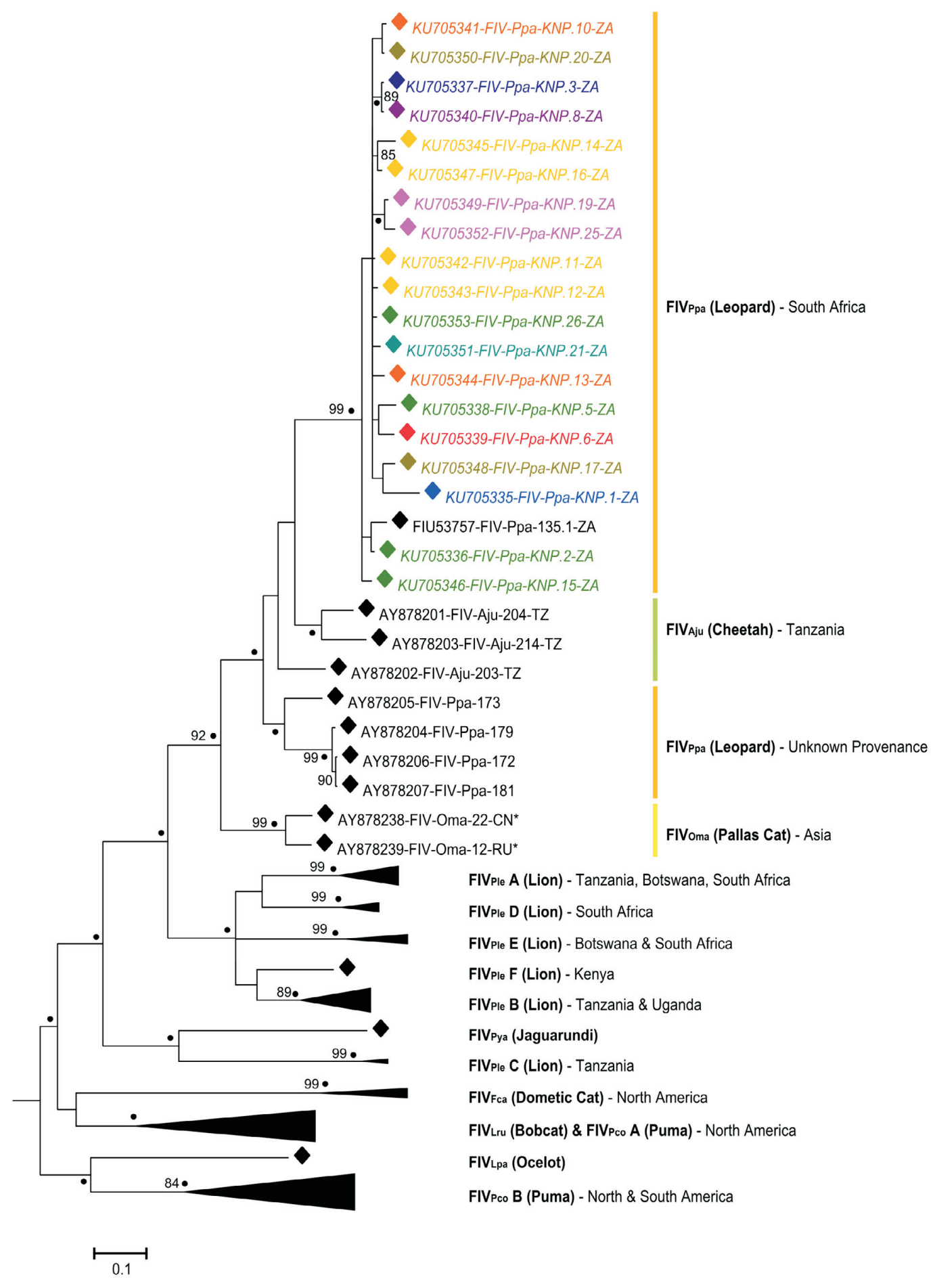

Fig. 3. Bayesian tree of 92 FIV pol-RT sequences (369 bp) comparing all available FIV Ppa sequences $(n=24)$ to the proposed FIV pol-RT reference dataset. Posterior probabilities $\geq 0.95$ are indicated with ' $\bullet$ '. ML Bootstrap values above $70 \%$ (1000 iterations) are also indicated. The tree is midpoint rooted. Each sequence is designated as in Fig. 2. Novel FIV $\mathrm{Ppa}_{\mathrm{S}}$ sequences isolated from KNP leopards are colour coded to correspond with the sampling locations in Fig. 1. 

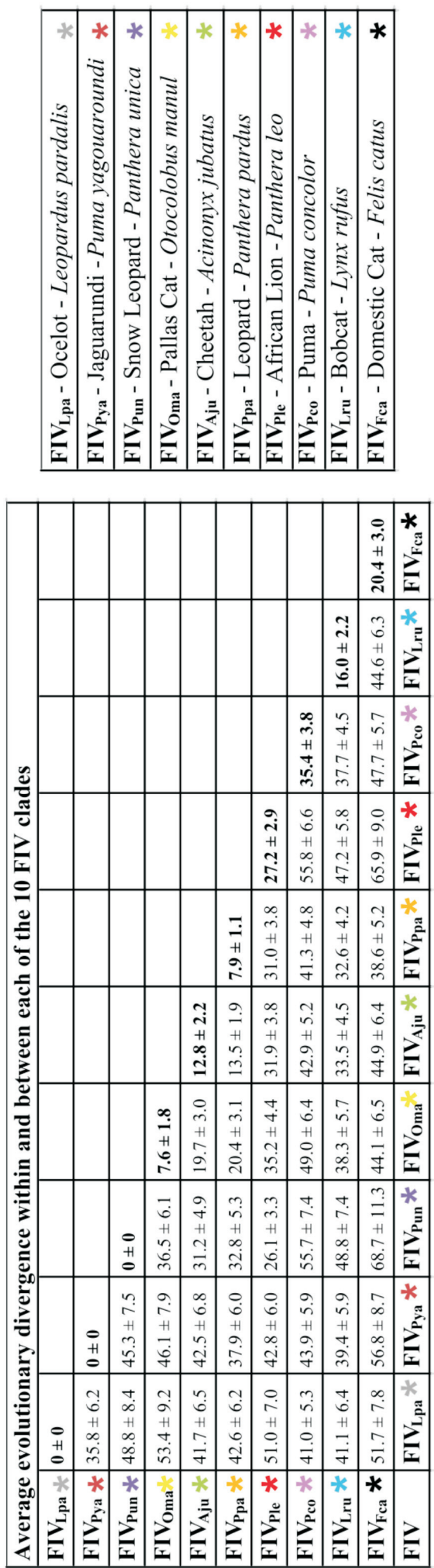

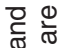

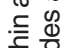

$\frac{\pi}{0}$

过

으ㅇㅡㅡ

$\sum^{\frac{0}{0}} \sum^{\frac{\pi}{2}}$

ฮั

ते

क⿻

릉

은

ब

$\stackrel{\infty}{\circ}$

무

茫

ब

तั

त)

है

कू

올

วิํㅡㅇ

क

¿

赵

응 웅

응 응

일. 들

힌

엉 운

$\subseteq$ ․ㅡ

훙이 옥릉

응 중ㅎํ

응 흥

क्ञ

40

ब 8

웅

क ळ

$5 \approx$ क

잉

웡

눙 $\frac{\pi}{\overline{0}}$.

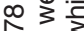

흥

응 등

뜽

넚는 주으 웅

क잉.

D

긍

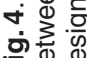

운 
tially within felid species depending on geographic area and study design (Brown et al., 1993; Osofsky et al., 1996; Troyer et al., 2005).

The seroprevalence and PCR prevalence of above $70 \%$ detected in KNP leopards is higher than the seroprevalence of FIV detected in the seven non-domestic solitary felid species (puma, bobcat, cheetah, Pallas cat, ocelot, jaguarundi, snow leopard). Only lions which are considered to be the only truly social cats (Spencer et al., 1992; Stuart \& Stuart, 2007) have an overlapping or higher seroprevalence of FIV ranging from $67-100 \%$ (Olmsted et al., 1992; Brown et al., 1993; Troyer et al., 2005; Roelke et al., 2009). The relatively high prevalence of FIV in the KNP leopard population could potentially be associated with the relatively high density of leopards in KNP, which would increase the potential for intraspecific interactions and the transmission of FIV (Franklin et al., 2008). Most habitat types within KNP support leopard densities between 12.7-30.3 individuals $/ 100 \mathrm{~km}^{2}$ (Chase Grey, Kent \& Hill, 2013; Maputla, 2014) which exceeds densities in other parts of South Africa (0.6-11.11/100 km²) (Chapman \& Balme, 2010; Martins, 2011; Swanepoel, Somers \& Dalerum, 2015), Botswana (6.9-7.5/100 $\left.\mathrm{km}^{2}\right)$ (Steyn, 2007), Namibia (1-3.6/100 km²) (Stein, Fuller, DeStefano \& Marker, 2011), East Africa (3.8-8.5/100 km²) (Mizutani \& Jewell, 1998) and West Africa (2.7-12.1/100 km²) (Jenny, 1996). Another possibility for the higher infection rates in KNP than elsewhere on the African continent may be related to sampling bias. In contrast to the study by Osofsky et al. (1996) where all leopard samples originated from legal hunting, a large percentage of the animals in the current study were animals caught in baited cage traps. It is possible that baited traps selected for animals in lower body condition (Bisi et al., 2011), since these animals are most likely immune compromised and can thus benefit more through engaging in riskier behaviour in order to benefit from food incentives.

Age-related infection has previously been observed in both solitary and social felids including African lions ( FIV $_{\text {Ple }}$ ) (Spencer et al., 1992; Adams et al., 2009), pumas (FIV Pco ) (Biek et al., 2003) and bobcats (FIV ${ }_{\text {Lru }}$ ) (Lee et al., 2012). Based on a small samples size used in the present study, FIV prevalence in leopards in the KNP also appears to increase with age, with less than $50 \%$ of subadult leopards infected and over $80 \%$ of adult leopards infected. From our data, there also appears to be no difference in the overall prevalence of FIV between male and female leopards. The latter suggests that differences in life history between males and females (such as social contact and aggression) is not playing a large role in the transmission of FIV in leopards.

\section{Phylogenetic analysis and sequence diversity of FIV pol-RT sequences}

Analyses of the updated and revised FIV pol-RT reference dataset (Supplementary Material) includes sequences previously not included in broad scale FIV studies and thus provides the most up to date analysis of all currently published FIV strains. Troyer et al. (2005) previously described FIV $_{\mathrm{Ppa}}$ as monophyletic; we suggest here the possibility of two distinct monophyletic groups within FIV $_{\mathrm{Ppa}}$ and therefore the possibility of two discrete FIV $_{\mathrm{Ppa}}$ subtypes. By comparing the two FIV pol-RT lineages observed in leopards to the $\mathrm{FIV}_{\mathrm{Ple}}$ subtypes observed in lions, some additional inferences can be made. Previous studies on lions suggested that subtypes diversify based on geographic location (Antunes et al., 2008), such as FIV $_{\text {Ple }}$ subtype A (southern African and East African Isolate) which forms two geographically isolated monophyletic clades (Fig. 2). Since the genetic diversity within $\mathrm{FIV}_{\mathrm{Ppa}}$ is less than the divergence between previously described FIV $_{\text {Ple }}$ subtypes it is more likely a single monophyletic $\mathrm{FIV}_{\mathrm{Ppa}}$ clade as suggested by Troyer et al. (2005), but may be subdivided due to geographic location of the host species. Since to date only well-studied FIV strains $\left(\mathrm{FIV}_{\mathrm{Fca}}, \mathrm{FIV}_{\mathrm{Pco}}\right.$ and $\mathrm{FIV}_{\mathrm{Ple}}$ ) have been divided into subtypes (Fig. 2; Fig. 4), an expanded geographic sampling of leopard FIV is needed to provide more clarity.

Should the paraphyletic clustering of leopard FIV, and the low sequence divergence between FIV $_{\mathrm{Ppa}}$ and FIV $\mathrm{Fiju}_{\mathrm{Aj}}$ hold, then it is interesting to speculate about the potential evolutionary mechanisms involved. It is well established that virus strains isolated from different species of felids often cluster according to the geographic region of host species rather than the strict phylogenetic relationships of the hosts (Franklin et al., 2007; Troyer et al., 2008). Our phylogenetic tree suggests that KNP leopards share a FIV strain that is closer to FIV isolated from Tanzanian cheetah than to other leopards sampled outside KNP (Fig. 3). This finding does not fully corroborate the idea that host switching among felid species is facilitated by taxa sharing overlapping geographic ranges (Franklin et al., 2007; Troyer et al., 2008). In the case of the KNP leopard 
population, it is more parsimonious to suggest that the FIV $\mathrm{Ppa}_{\mathrm{Pp}}$ sequences isolated from leopards carry a signal of ancestral cross-species infection between leopard and cheetah since these sequences group together nested within a larger clade. However, the similar sequence diversity within $\operatorname{FIV}_{\text {Aja }}(12.8 \pm 2.2 \%$; Fig. 4) when compared to the sequence divergence between FIV $\mathrm{Ppa}_{\mathrm{Pa}}$ and $\operatorname{FIV}_{\text {Aja }}(13.5 \pm 1.9 \%$; Fig. 4), and the paraphyletic clustering of $\mathrm{FIV}_{\mathrm{Ppa}}$ may also suggest that these two species-specific stains of FIV are in fact polyphyletic and not fully diverged from each other. Additional cheetah and leopard samples are clearly needed to obtain a more accurate assessment of the mechanisms involved in the evolution of leopard FIV.

At the smaller geographic scale, within the KNP sampled population, there appears to be an absence of geographic structure related to the sampling location of the individual leopards and their associated viral sequences. In five of the seven cases where $\mathrm{FIV}_{\mathrm{Ppa}}$ lineages cluster together, the hosts originated from different sampling localities (Fig. 1; Fig. 3). These close evolutionary associations among the lineages is further supported by the low genetic diversity of $\mathrm{FIV}_{\mathrm{Ppa}}$ within KNP $(4.1 \pm 0.7 \%)$.

The discovery of a high prevalence and seemingly geographically structured FIV $_{\mathrm{Ppa}}$ strains has some conservation relevance. It has been reported that the pathogenic effects of FIV may vary between the different strains of FIV but in some instances inferences on pathogenic potential is highly speculative (Brown et al., 1994; Hofmann-Lehmann et al., 1996; Pecon-Slattery et al., 2008a; Adams et al., 2009). As mentioned previously, there is still much speculation surrounding the pathogenic potential of FIV in wild felids. It has been suggested that wild felids may be tolerant to their speciesspecific FIV strains (Carpenter \& O'Brien, 1995). However, more recent studies have recorded that FIV $_{\text {Ple }}$ positive lions develop lymphocyte deficiencies, shown by a decrease in the total number of CD4+ and CD8+ T-cells and highlights the importance of monitoring the number of CD4+ cells in infected animals to examine disease progression (Bull et al., 2003; Roelke et al., 2006). In addition, Roelke et al. (2009) found that lions infected with FIV $_{\text {Ple }}$ exhibit symptoms associated with immunodeficiency viruses (HIV, SIV and FIV Fca ) such as poor overall health and condition, oral lesions (gingivitis and oral papillomas), dehydration, abnormal red blood cell parameters and evidence of lymphadenopathy (enlarged lymph nodes). Considering this and the high prevalence of $\mathrm{FIV}_{\mathrm{Ppa}}$ detected in leopards we could speculate that the KNP leopard population may be at risk of disease, and thus recommend long-term monitoring of the individuals identified as FIV positive in this study. This will provide new insights into disease progression in wild leopards and can aid in the conservation of this threatened large felid species.

Although our study is based on limited sampling, in a small geographic area, it highlights the need for more systematic sampling of FIV in many felid species. These data are critically needed to better understand the real distribution and prevalence of FIV, how the virus changes over time, what role cross-species infections play and most importantly whether FIV infection pose a significant conservation risk to the health of free-ranging felines.

\section{SUPPLEMENTARY MATERIAL}

Supporting text: FIV pol-RT Reference Dataset.

Fig. S1. Flow chart showing how the FIV pol-RT reference dataset was complied, indicating inclusion and exclusion criteria.

Table S1. Metadata FIV pol-RT Reference Dataset.

\section{ACKNOWLEDGEMENTS}

The authors would like to thank SANParks for the opportunity to participate in this research. Ethical approval for this project was obtained from the South African National Parks Animal Use and Care Committee (Protocol \#: 589MAPNW) and the Stellenbosch University Research Ethics Committee: Animal Care and Use (Protocol \#: SU-ACUM12-00038). T.J. Kerr was the recipient of a National Research Foundation Grant-Holder Linked Student Support Bursary (Grant Number: 74463); National Research Foundation Scarce Skills Doctoral Scholarship (Grant Number: 89620); Poliomyelitis Research Foundation Masters Bursary (Grant Number: 13/34) and Ph.D. Bursary (Grant Number: 14/50). Project funding for laboratory analysis at Division of Medical Virology, Department of Pathology, Faculty of Medicine and Health Science, Stellenbosch University, was provided by the Poliomyelitis Research Foundation (Grant Number: 13/08) to S. Engelbrecht. The Grant holder acknowledges that opinions, findings and conclusions or recommendations expressed in any publication generated by the NRF-supported research is those of the authors, and that the NRF accepts no liability whatsoever in this regard. 


\section{REFERENCES}

Adams, H., van Vuuren, M., Bosman, A-M., Keet, D., New, J. \& Kennedy, M. (2009). The epidemiology of lion lentivirus infection among a population of free-ranging lions (Panthera leo) in the Kruger National Park, South Africa. Journal of the South African Veterinary Association, 80(3), 151-156.

Altschul, S.F., Gish, W., Miller, W., Myers, E. W. \& Lipman, D. J. (1990). Basic local alignment search tool. Journal of Molecular Biology, 215(3), 403-410.

Antunes, A., Troyer, J.L., Roelke, M.E., Pecon-Slattery, J., Packer, C., Winterbach, C., Winterbach, H., Hemson, G., Frank, L., Stander, P., Siefert, L., Driciru, M., Funston, P.J., Alexander, K.A., Prager, K.C., Mills, G., Wildt, D., Bush, M., O’Brien, S.J. \& Johnson, W.E. (2008). The evolutionary dynamics of the lion Panthera leo revealed by host and viral population genomics. PLOS Genetics, 4(11), e1000251.

Bendinelli, M., Pistello, M., Lombardi, S., Poli, A., Garzelli, C., Matteucci, D., Ceccherininelli, L., Malvaldi, G. \& Tozzini, F. (1995). Feline Immunodeficiency Virus: an interesting model for AIDS studies and an important cat pathogen. Clinical Microbiology Reviews, 8(1), 87-112.

Biau, D.J., Kerneis, S. \& Porcher, R. (2008). Statistics in brief: the importance of sample size in the planning and interpretation of medical research. Clinical Orthopaedics and Related Research, 466(9), 22822288.

Biek, R., Rodrigo, A.G., Holley, D., Drummond, A., Anderson, C.R., Ross, H.A. \& Poss, M. (2003). Epidemiology, genetic diversity, and evolution of endemic Feline Immunodeficiency Virus in a population of wild cougars. Journal of Virology, 77(17), 9578-9589.

Bisi, F., Newey, S., Nodari, M., Wauters, L.A., Harrison, A., Thirgood, S. \& Martinoli, A. (2011). The strong and the hungry: bias in capture methods for mountain hares Lepus timidus. Wildlife Biology, 17(3), 311316.

Brown, E.W., Miththapala, S. \& O’Brien, S.J. (1993). Prevalence of exposure to Feline Immunodeficiency Virus in exotic felid species. Journal of Zoo and Wildlife Medicine, 24(3), 357-364.

Brown, E.W., Yuhki, N., Packer, C. \& O’Brien, S.J. (1994). A lion lentivirus related to Feline Immunodeficiency Virus: epidemiologic and phylogenetic aspects. Journal of Virology, 68(9), 5953-5968.

Brown, M.A., Munkhtsog, B., Troyer, J.L., Ross, S., Sellers, R., Fine, A.E., Swanson, W.F., Roelke, M.E. \& O'Brien, S.J. (2010). Feline immunodeficiency virus (FIV) in wild Pallas' cats. Veterinary Immunology and Immunopathology, 134(1-2), 90-95.

Bull, M.E., Kennedy-Stoskopf, S., Levine, J.F., Loomis, M., Gebhard, D.G. \& Tompkins, W. A. F. (2003). Evaluation of $\mathrm{T}$ lymphocytes in captive African lions (Panthera leo) infected with Feline Immunodeficiency Virus. American Journal of Veterinary Research, 64(10), 1293-1300.

Carpenter, M.A., Brown, E.W., Culver, M., Johnson, W.E., Pecon-Slattery, J., Brousset, D. \& O'Brien, S.J. (1996). Genetic and phylogenetic divergence of Feline Immunodeficiency Virus in the puma (Puma concolor). Journal of Virology, 70(10), 6682-6693.
Carpenter, M.A. \& O’Brien, S.J. (1995). Coadaptation and Immunodeficiency Virus: lessons from the Felidae. Current Opinion in Genetics \& Development, 5(6), 739-745.

Chapman, S. \& Balme, G. (2010). An estimate of leopard population density in a private reserve in KwaZuluNatal, South Africa, using camera-traps and capture-recapture models. South African Journal of Wildlife Research, 40(2), 114-120.

Chase Grey, J.N., Kent, V.T. \& Hill, R.A. (2013). Evidence of a high density population of harvested leopards in a montane environment. PLOS ONE, 8(12), e82832-e82832.

Franklin, S.P., Kays, R.W., Moreno, R., TerWee, J.A., Troyer, J.L. \& VandeWoude, S. (2008). Ocelots on Barro Colorado Island are infected with Feline Immunodeficiency Virus but not other common feline and canine viruses. Journal of Wildlife Diseases, 44(3), 760-765.

Franklin, S.P., Troyer, J.L., Terwee, J.A., Lyren, L.M., Boyce, W.M., Riley, S.P.D., Roelke, M.E., Crooks, K.R. \& VandeWoude, S. (2007). Frequent transmission of immunodeficiency viruses among bobcats and pumas. Journal of Virology, 81(20), 1096110969.

Henschel, P., Huelsenbeck, J.P., Breitenmoser, U., Purchase, N., Packer, C., Khorozyan, I., Bauer, H., Marker, L., Sogbohossou, E. \& BreitenmoserWursten, C. (2008). Panthera pardus, Leopard. The IUCN Red List of Threatend Species 2008: e.T15954A5329380, http://dx.doi.org/10.2305/IUCN.UK. 2008.RLTS.T15954A5329380.en

Hofmann-Lehmann, R., Fehr, D., Grob, M., Elgizoli, M., Packer, C., Martenson, J.S., O'Brien, S.J. \& Lutz, H. (1996). Prevalence of antibodies to Feline Parvovirus, Calicivirus, Herpesvirus, Coronavirus, and Immunodeficiency Virus and of Feline Leukemia Virus antigen and the interrelationship of these viral infections in free-ranging lions in East Africa. Clinical and Diagnostic Laboratory Immunology, 3(5), 554562.

Huelsenbeck, J.P. \& Ronquist, F. (2001). MRBAYES: Bayesian inference of phylogenetic trees. Bioinformatics, 17(8), 754-755.

Jenny, D. (1996). Spatial organization of leopards Panthera pardus in Tai National Park, Ivory Coast: Is rain forest habitat a 'tropical haven'? Journal of Zoology, 240, 427-440.

Johnson, W.E., Eizirik, E., Pecon-Slattery, J., Murphy, W.J., Antunes, A., Teeling, E. \& O'Brien, S.J. (2006). The Late Miocene radiation of modern Felidae: a genetic assessment. Science, 311(5757), 73-77.

Larkin, M.A., Blackshields, G., Brown, N.P., Chenna, R., McGettigan, P.A., McWilliam, H., Valentin, F., Wallace, I.M., Wilm, A., Lopez, R., Thompson, J.D., Gibson, T.J. \& Higgins, D.G. (2007). Clustal W and Clustal $X$ version 2.0. Bioinformatics, 23(21), 2947-2948.

Lee, J.S., Ruell, E.W., Boydston, E.E., Lyren, L.M., Alonso, R.S., Troyer, J.L., Crooks, K.R. \& VandeWoude, S. (2012). Gene flow and pathogen transmission among bobcats (Lynx rufus) in a fragmented urban landscape. Molecular Ecology, 21(7), 16171631. 
Macdonald, D.W. \& Loveridge, A.J. (2010). Biology and conservation of wild felids. New York U.S.A.: Oxford University Press.

Maputla, N.W. (2014). Drivers of leopard population dynamics in the Kruger National Park, South Africa. (Unpublished Ph.D. thesis). Pretoria, South Africa: University of Pretoria.

Martins, Q.E. (2011). The ecology of the leopard Panthera pardus in the Cederberg Mountains. (Unpublished Ph.D. thesis). Bristol, U.K.: University of Bristol.

Miller, R.J., Cairns, J.S., Bridges, S. \& Sarver, N. (2000). Human Immunodeficiency Virus and AIDS: insights from animal lentiviruses. Journal of Virology, 74(16), 7187-7195.

Mizutani, F. \& Jewell, P.A. (1998). Home-range and movements of leopards (Panthera pardus) on a livestock ranch in Kenya. Journal of Zoology, London, 244, 269-286.

Nei, M. \& Kumar, S. (2000). Molecular evolution and phylogenetics. New York U.S.A.: Oxford University Press.

O'Brien, S.J., Troyer, J.L., Brown, M.A., Johnson, W.E., Antunes, A., Roelke, M.E. \& Pecon-Slattery, J. (2012). Emerging viruses in the Felidae: shifting paradigms. Viruses, 4(2), 236-257.

O’Brien, S.J., Troyer, J.L., Roelke, M., Marker, L. \& Pecon-Slattery, J. (2006). Plagues and adaptation: Lessons from the Felidae models for SARS and AIDS. Biological Conservation, 131(2), 255-267.

Olmsted, R.A., Barnes, A.K., Yamamoto, J.K., Hirsch, V.M., Purcell, R.H. \& Johnson, P.R. (1989a). Molecular cloning of Feline Immunodeficiency Virus. Proceedings of the National Academy of Sciences of the United States of America, 86(7), 2448-2452.

Olmsted, R.A., Hirsch, V.M., Purcell, R.H. \& Johnson, P.R. (1989b). Nucleotide sequence analysis of Feline Immunodeficiency Virus: Genome organization and relationship to other Lentiviruses. Proceedings of the National Academy of Sciences of the United States of America, 86(20), 8088-8092.

Olmsted, R.A., Langley, R., Roelke, M.E., Goeken, R.M., Adger-Johnson, D., Goff, J.P., Albert, J.P., Packer, C., Laurenson, M.K., Caro, T.M., Scheepers, L., Wildt, D.E., Bush, M., Martenson, J.S. \& O'Brien, S.J. (1992). Worldwide prevalence of lentivirus infection in wild feline species: epidemiologic and phylogenetic aspects. Journal of Virology, 66(10), 60086018.

Osofsky, S.A., Hirsch, K.J., Zuckerman, E.E. \& Hardy, W.D. (1996). Feline Lentivirus and Feline Oncovirus status of free-ranging lions (Panthera leo), leopards (Panthera pardus), and cheetahs (Acinonyx jubatus) in Botswana: a regional perspective. Journal of Zoo and Wildlife Medicine, 27(4), 453-467.

Pecon-Slattery, J., McCracken, C.L., Troyer, J.L., VandeWoude, S., Roelke, M., Sondgeroth, K., Winterbach, C., Winterbach, H. \& O'Brien, S.J. (2008a). Genomic organization, sequence divergence, and recombination of Feline Immunodeficiency Virus from lions in the wild. BMC Genomics, 9(66): 1-13.

Pecon-Slattery, J., Troyer, J.L., Johnson, W. E. \& O’Brien, S.J. (2008b). Evolution of Feline Immunodeficiency
Virus in Felidae: implications for human health and wildlife ecology. Veterinary Immunology and Immunopathology, 123(1-2), 32-44.

Pedersen, N.C., Yamamoto, J.K., Ishida, T. \& Hansen, H. (1989). Feline Immunodeficiency Virus infection. Veterinary Immunology and Immunopathology, 21(1), 111-129.

Roelke, M.E., Brown, M.A., Troyer, J.L., Winterbach, H., Winterbach, C., Hemson, G., Smith, D., Johnson, R.C., Pecon-Slattery, J., Roca, A. L., Alexander, K.A., Klein, L., Martelli, P., Krishnasamy, K. \& O’Brien, S.J. (2009). Pathological manifestations of Feline Immunodeficiency Virus (FIV) infection in wild African lions. Virology, 390(1), 1-12.

Roelke, M.E., Pecon-Slattery, J., Taylor, S., Citino, S., Brown, E., Packer, C., VandeWoude, S. \& O'Brien, S.J. (2006). T-lymphocyte profiles in FIV-infected wild lions and pumas reveal CD4 depletion. Journal of Wildlife Diseases, 42(2), 234-248.

SANParks. (2015). Standard operating procedures for the capture, transportation and maintenance in holding facilities of wildlife, 2nd edition. Resource held at South African National Parks, Pretoria, South Africa.

Skinner, J.D. \& Chimimba, C.T. (2005). The mammals of the southern African Subregion (3rd edn). Cape Town, South Africa: Cambridge University Press.

Spencer, J.A., Vandijk, A.A., Horzinek, M.C., Egberink, H.F., Bengis, R.G., Keet, D.F., Morikawa, S. \& Bishop, D.H.L. (1992). Incidence of Feline Immunodeficiency Virus reactive antibodies in free-ranging lions of the Kruger National Park and the Etosha National Park in southern Africa detected by recombinant FIV p24 antigen. Onderstepoort Journal of Veterinary Research, 59(4), 315-322.

Stein, A.B., Athreya, V., Gerngross, P., Balme, G., Henschel, P., Karanth, U., Miquelle, D., Rostro, S., Kamler, J.F. \& Laguardia, A. (2016). Panthera pardus, Leopard. The IUCN Red List of Threatened Species 2016: e.T15954A50659089, http://dx.doi.org/ 10.2305/IUCN.UK.2016-2301.RLTS.T15954A50659 089.en

Stein, A.B., Fuller, T.K., DeStefano, S. \& Marker, L.L. (2011). Leopard population and home range estimates in north-central Namibia. African Journal of Ecology, 49(3), 383-387.

Steyn, P.D.V. (2007). The socio-spatial organisation of leopards (Panthera pardus) in the northern Tuli Game Reserve, Botswana. (Unpublished M.Tech. thesis). Pretoria, South Africa: Tshwane University of Technology.

Stuart, C. \& Stuart, T. (2007). Field guide to mammals of southern Africa (4th edn). Cape Town, South Africa: Struik Publishers.

Swanepoel, L.H., Somers, M.J. \& Dalerum, F. (2015). Density of leopards Panthera pardus on protected and non-protected land in the Waterberg Biosphere, South Africa. Wildlife Biology, 21(5), 263-268.

Tamura, K., Stecher, G., Peterson, D., Filipski, A. \& Kumar, S. (2013). MEGA6: Molecular Evolutionary Genetics Analysis Version 6.0. Molecular Biology and Evolution, 30(12), 2725-2729.

Troyer, J.L., Pecon-Slattery, J., Roelke, M.E., Black, L., Packer, C. \& O'Brien, S.J. (2004). Patterns of Feline 
Immunodeficiency Virus multiple infection and genome divergence in a free-ranging population of African lions. Journal of Virology, 78(7), 37773791.

Troyer, J.L., Pecon-Slattery, J., Roelke, M.E., Johnson, W., VandeWoude, S., Vazquez-Salat, N., Brown, M., Frank, L., Woodroffe, R., Winterbach, C., Winterbach, H., Hemson, G., Bush, M., Alexander, K.A., Revilla, E. \& O'Brien, S.J. (2005). Seroprevalence and genomic divergence of circulating strains of Feline Immunodeficiency Virus among Felidae and Hyaenidae species. Journal of Virology, 79(13), 82828294.

Troyer, J.L., VandeWoude, S., Pecon-Slattery, J.,
Mclntosh, C., Franklin, S., Antunes, A., Johnson, W. \& O'Brien, S.J. (2008). FIV cross-species transmission: an evolutionary prospective. Veterinary Immunology and Immunopathology, 123(1-2), 159166.

VandeWoude, S. \& Apetrei, C. (2006). Going wild: Lessons from naturally occurring T-lymphotropic lentiviruses. Clinical Microbiology Reviews, 19(4), 728-762.

VandeWoude, S., O'Brien, S.J., Langelier, K., Hardy, W.D., Slattery, J.P., Zuckerman, E.E. \& Hoover, E.A. (1997). Growth of lion and puma lentiviruses in domestic cat cells and comparisons with FIV. Virology, 233(1), 185-192.

Responsible Editor: G.I.H. Kerley 


\section{Supplementary material to:}

T.J. Kerr, C. Matthee, S. Matthee, D. Govender \& S. Engelbrecht,

Evaluating the diversity of the Feline Immunodeficiency Virus (FIV): a leopard perspective, African Journal of Wildlife Research 47(2): 92-105 (October 2017) 


\section{Supporting Text - FIV pol-RT Reference Dataset}

\section{Materials and Methods}

Developing a reference dataset of FIV pol-RT sequences for comparative analysis

All available FIV sequences isolated from non-domestic felid species were downloaded from GenBank using a search executed in Geneious Version 8 (Kearse et al., 2012). The FIV sequences were then sorted by gene region, felid species from which the sequence was isolated, and author. For this study, we focused specifically on the FIV pol-RT gene region. To standardize the FIV pol-RT reference dataset, all sequences with stop codons in the first reading frame were excluded. FIV isolated from the domestic cat $\left(\mathrm{FIV}_{\mathrm{Fca}}\right)$, and the novel FIV pol-RT sequences isolated from leopards $\left(\mathrm{FIV}_{\mathrm{Ppa}}\right)$ were added. Due to the variability in sequence length, ends from the FIV pol-RT reference dataset were trimmed and then subjected to multiple sequence alignment (Fig. S1 - Supplementary Material) using ClustalX Version 2.1 (Larkin et al., 2007). Sequence alignment was also optimized by using Codon Alignment Version 2.1.0 (http://www.hiv.lanl.gov) and manual adjustment. A 421bp fragment that included all FIV strains was generated from the alignment. Percentage identity between sequences in the database was then determined using uncorrected p-values. Sequence selection/retention was done in such a way as to maximize the variation and the geographic range of sampling. For sequences that had a percentage identity score of between $95 \%$ and $100 \%$, only one sequence was retained, except in cases where sequences were more than 95\% similar, but isolated from different felid species. To exclude all missing data, the resulting FIV pol-RT reference dataset was further trimmed to a final alignment length of 369bp (Fig. S1; Table S1 - Supplementary Material).

\section{FIV sequence nomenclature}

For ease of reference when interpreting phylogenetic trees, each FIV pol-RT sequence was designated by a unique sequence name (for example FIU53757-FIV-Ppa-135.1-ZA or FIU05996-FIV-Plekp177.9-A-TZ) comprising an accession number as obtained from GenBank, virus abbreviation, felid species from which sample was collected (abbreviated genus and species identifiers as a 3 letter code), individual sample ID (as designated in each individual study), FIV subtype (for felid species where FIV subtypes have previously been identified), two-letter country code as designated by the International Organisation for Standardisation (ISO 3166 Country Codes). FIV $\mathrm{Ple}_{\text {and }}$ FIV $_{\text {Pco }}$ sequences that had not been assigned a subtype in their GenBank entry were identified by means of a BLAST search and assigned a subtype accordingly. 


\section{Results}

\section{FIV pol-RT reference dataset}

The overall number of FIV sequences included in the proposed updated FIV pol-RT reference dataset comprised 78 sequences (Fig. S1; Table S1 - Supplementary Material). Noticeable differences between the updated FIV pol-RT reference dataset and the one used by Troyer et al. (2005) is the inclusion of FIV $_{\text {Ple }}$ subtype E sequences isolated by Adams, van Vuuren, Bosman, Kania, and Kennedy (2011), six FIV $\mathrm{Lru}_{\text {Lru }}$ sequences isolated from bobcats (Franklin et al., 2007), one previously published leopard (FIV $\mathrm{Ppa}_{\text {a }}$ ) sequence (Carpenter et al., 1996) and seven novel FIV $_{\mathrm{Ppa}}$ sequences isolated from South African leopards from the KNP as found herein. In the present dataset, it was decided to exclude the FIV $_{\text {Crr }}$ sequences isolated from spotted hyena to limit missing data (the FIV $\mathrm{Ccr}_{\text {cr }}$ sequences in GenBank are <350bp).

\section{Discussion}

\section{FIV pol-RT reference dataset}

Reviewing all previously published FIV pol-RT sequences isolated from wild felids, and the development of an updated FIV pol-RT reference dataset was prompted by the absence of an updated predefined reference dataset against which to compare novel FIV sequences of leopard. The variability in length of the FIV pol-RT sequences and the resulting alignment was the limiting factor in the development of the proposed FIV pol-RT reference dataset (Fig. 2; Fig. S1- Supplementary Material). For well-studied species such as the domestic cat, African lion, bobcat and puma there is an abundance of FIV pol-RT sequences of variable lengths (Olmsted et al., 1989a; Olmsted, Hirsch, Purcell, \& Johnson, 1989b; Talbott et al., 1989; Phillips et al., 1990; Olmsted et al., 1992; Brown, Yuhki, Packer, \& O'Brien, 1994; Langley et al., 1994; Sodora et al., 1995; Carpenter et al., 1996; Biek et al., 2003; de Rozieres et al., 2004; Troyer et al., 2005; Poss et al., 2006; Franklin et al., 2007; Antunes et al., 2008; Adams et al., 2011; Lee et al., 2012), while for the less well-studied species such as leopard, cheetah, Pallas cat, ocelot, jaguarundi, snow leopard and spotted hyena there are few FIV pol-RT sequences and the fragment length is generally short (Carpenter et al., 1996; Troyer et al., 2005; Brown et al., 2010). Final sequence selection was therefore determined by the shortest sequences and the final alignment was less than $400 \mathrm{bp}$. In addition, we chose to exclude FIV pol-RT sequences isolated from spotted hyena, firstly as they are not Felidae (Johnson et al., 2006; Stuart \& Stuart, 2007), and secondly their inclusion would further reduce the size/length of the final alignment. As both additional sequences and longer sequences become available for all felid species, the proposed FIV pol-RT reference dataset will need to be updated. Sequences isolated from jaguarundi, in particular, should be entered into GenBank using the revised species name Puma 
yagouaroundi formerly Herpailurus yagouaroundi and the updated virus abbreviation FIV $_{\text {Pya. }}$ For this study, the single jaguarundi sequence is designated using FIV $_{\text {Pya }}$ as per the revised species name.

The FIV pol-RT reference dataset advances our current knowledge on FIV given that phylogenetic analysis of all previously published FIV pol-RT sequences revealed cases where identical sequences isolated from the same individual felid occur multiple times in GenBank under different accession numbers (Table S1 - Supplementary Material). Unlike HIV, previous studies have not made use of a standardised naming system for all FIV sequences. We would like to propose the inclusion of essential information when constructing phylogenetic trees that would aid in the subsequent interpretation of phylogenetic trees. We suggest as outlined in the Materials and Methods, that each FIV pol-RT sequence is designated by a unique sequence name for inclusion in the phylogenetic analysis.

\section{References}

Adams, H. R., van Vuuren, M., Bosman, A.-M., Kania, S., \& Kennedy, M. A. (2011). Detection and genetic analysis of Feline Immunodeficiency Virus $\left(\mathrm{FIV}_{\mathrm{Ple}}\right)$ in southern African lions (Panthera leo). South African Journal of Wildlife Research, 41 (2), 173-180

Antunes, A., Troyer, J. L., Roelke, M. E., Pecon-Slattery, J., Packer, C., Winterbach, C., Winterbach, H., Hemson, G., Frank, L., Stander, P., Siefert, L., Driciru, M., Funston, P. J., Alexander, K. A., Prager, K. C., Mills, G., Wildt, D., Bush, M., O'Brien, S. J., \& Johnson, W. E. (2008). The evolutionary dynamics of the lion Panthera leo revealed by host and viral population genomics. PLoS Genetics, 4 (11), e1000251

Biek, R., Rodrigo, A. G., Holley, D., Drummond, A., Anderson, C. R., Ross, H. A., \& Poss, M. (2003). Epidemiology, genetic diversity, and evolution of endemic Feline Immunodeficiency Virus in a population of wild cougars. Journal of Virology, 77 (17), 9578-9589

Brown, E. W., Yuhki, N., Packer, C., \& O'Brien, S. J. (1994). A lion lentivirus related to Feline Immunodeficiency Virus: epidemiologic and phylogenetic aspects. Journal of Virology, 68 (9), 5953-5968

Brown, M. A., Munkhtsog, B., Troyer, J. L., Ross, S., Sellers, R., Fine, A. E., Swanson, W. F., Roelke, M. E., \& O'Brien, S. J. (2010). Feline immunodeficiency virus (FIV) in wild Pallas' cats. Veterinary Immunology and Immunopathology, 134 (1-2), 90-95

Carpenter, M. A., Brown, E. W., Culver, M., Johnson, W. E., PeconSlattery, J., Brousset, D., \& O'Brien, S. J. (1996). Genetic and phylogenetic divergence of Feline Immunodeficiency Virus in the puma (Puma concolor). Journal of Virology, 70 (10), 6682-6693

de Rozieres, S., Mathiason, C. K., Rolston, M. R., Chatterji, U., Hoover, E. A., \& Elder, J. H. (2004). Characterization of a highly pathogenic molecular clone of Feline Immunodeficiency Virus clade C. Journal of Virology, 78 (17), 8971-8982

Franklin, S. P., Troyer, J. L., Terwee, J. A., Lyren, L. M., Boyce, W. M., Riley, S. P. D., Roelke, M. E., Crooks, K. R., \& VandeWoude, S. (2007). Frequent transmission of immunodeficiency viruses among bobcats and pumas. Journal of Virology, 81 (20), 10961-10969

Johnson, W. E., Eizirik, E., Pecon-Slattery, J., Murphy, W. J., Antunes, A., Teeling, E., \& O'Brien, S. J. (2006). The Late Miocene radiation of modern Felidae: A genetic assessment. Science, 311 (5757), 73-77

Kearse, M., Moir, R., Wilson, A., Stones-Havas, S., Cheung, M., Sturrock, S., Buxton, S., Cooper, A., Markowitz, S., Duran, C., Thierer, T., Ashton, B., Meintjes, P., \& Drummond, A. (2012). Geneious Basic: An integrated and extendable desktop software platform for the organization and analysis of sequence data. Bioinformatics, 28 (12), 1647-1649 
Langley, R. J., Hirsch, V. M., O'Brien, S. J., Adger-Johnson, D., Goeken, R. M., \& Olmsted, R. A. (1994). Nucleotide sequence analysis of Puma Lentivirus (PLV-14): Genomic organization and relationship to other lentiviruses. Virology, 202 (2), 853-864

Larkin, M. A., Blackshields, G., Brown, N. P., Chenna, R., McGettigan, P. A., McWilliam, H., Valentin, F., Wallace, I. M., Wilm, A., Lopez, R., Thompson, J. D., Gibson, T. J., \& Higgins, D. G. (2007). Clustal W and Clustal X version 2.0. Bioinformatics, 23 (21), 2947-2948

Lee, J. S., Ruell, E. W., Boydston, E. E., Lyren, L. M., Alonso, R. S., Troyer, J. L., Crooks, K. R., \& VandeWoude, S. (2012). Gene flow and pathogen transmission among bobcats (Lynx rufus) in a fragmented urban landscape. Molecular Ecology, 21 (7), 1617-1631

Olmsted, R. A., Barnes, A. K., Yamamoto, J. K., Hirsch, V. M., Purcell, R. H., \& Johnson, P. R. (1989a). Molecular cloning of Feline Immunodeficiency Virus. Proceedings of the National Academy of Sciences of the United States of America, 86 (7), 2448-2452

Olmsted, R. A., Hirsch, V. M., Purcell, R. H., \& Johnson, P. R. (1989b). Nucleotide sequence analysis of Feline Immunodeficiency Virus: Genome organization and relationship to other Lentiviruses. Proceedings of the National Academy of Sciences of the United States of America, 86 (20), 8088-8092

Olmsted, R. A., Langley, R., Roelke, M. E., Goeken, R. M., Adger-Johnson, D., Goff, J. P., Albert, J. P., Packer, C., Laurenson, M. K., Caro, T. M., Scheepers, L., Wildt, D. E., Bush, M., Martenson, J. S., \& O'Brien, S. J. (1992). Worldwide prevalence of lentivirus infection in wild feline species: epidemiologic and phylogenetic aspects. Journal of Virology, 66 (10), 6008-6018

Phillips, T. R., Talbott, R. L., Lamont, C., Muir, S., Lovelace, K., \& Elder, J. H. (1990). Comparison of two host-cell range variants of Feline Immunodeficiency Virus. Journal of Virology, 64 (10), 4605-4613

Poss, M., Ross, H. A., Painter, S. L., Holley, D. C., Terwee, J. A., VandeWoude, S., \& Rodrig, A. (2006). Feline Lentivirus evolution in cross-species infection reveals extensive G-to-A mutation and selection on key residues in the viral polymerase. Journal of Virology, 80 (6), 2728-2737

Sodora, D. L., Courcelle, J., Brojatsch, J., Berson, A., Wang, Y. C., Dow, S. W., Hoover, E. A., \& Mullins, J. I. (1995). Analysis of a Feline Immunodeficiency Virus provirus reveals patterns of gene sequence conservation distinct from Human Immunodeficiency Virus Type 1. AIDS Research and Human Retroviruses, 11 (4), 531-533

Stuart, C., \& Stuart, T. (2007). Field Guide to Mammals of Southern Africa (4th ed.). Cape Town RSA: Struik Publishers.

Talbott, R. L., Sparger, E. E., Lovelace, K. M., Fitch, W. M., Pedersen, N. C., Luciw, P. A., \& Elder, J. H. (1989). Nucleotide sequence and genomic organization of Feline Immunodeficiency Virus. Proceedings of the National Academy of Sciences of the United States of America, 86 (15), 5743-5747

Troyer, J. L., Pecon-Slattery, J., Roelke, M. E., Johnson, W., VandeWoude, S., Vazquez-Salat, N., Brown, M., Frank, L., Woodroffe, R., Winterbach, C., Winterbach, H., Hemson, G., Bush, M., Alexander, K. A., Revilla, E., \& O'Brien, S. J. (2005). Seroprevalence and genomic divergence of circulating strains of Feline Immunodeficiency Virus among Felidae and Hyaenidae species. Journal of Virology, 79 (13), 8282-8294 


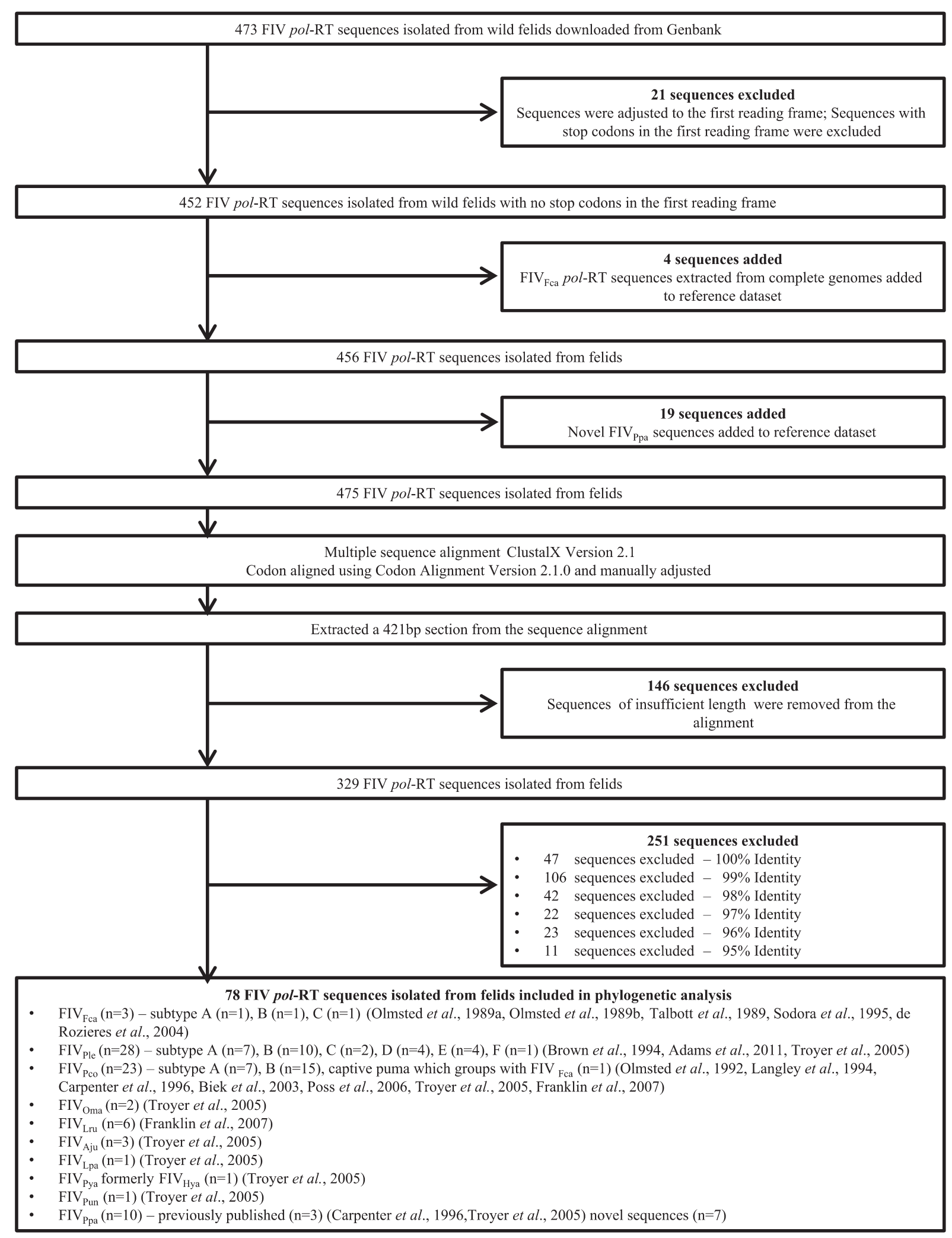

Fig. S1. Flow chart showing how the FIV pol-RT reference dataset was complied, indicating inclusion and exclusion criteria. 


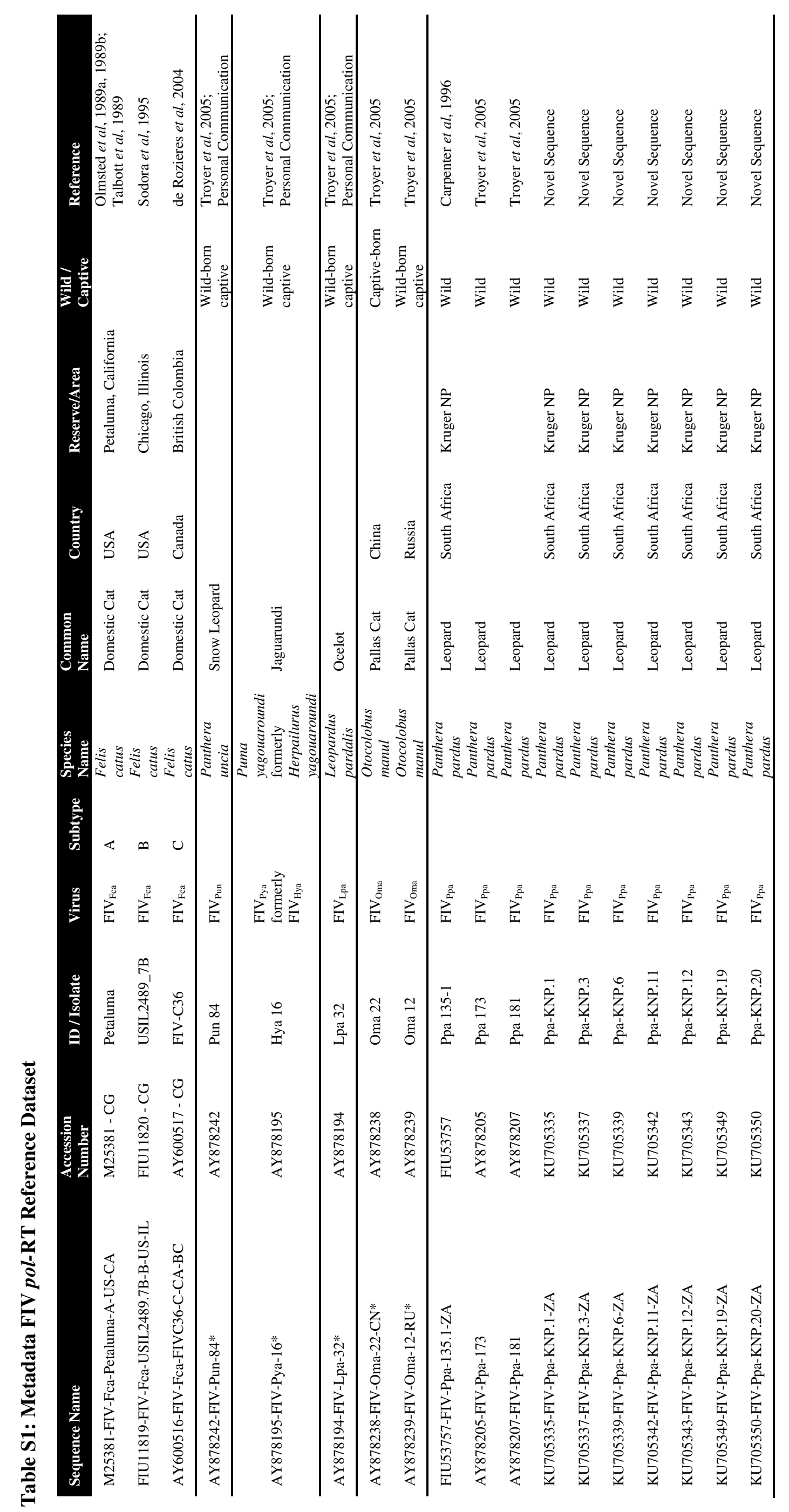




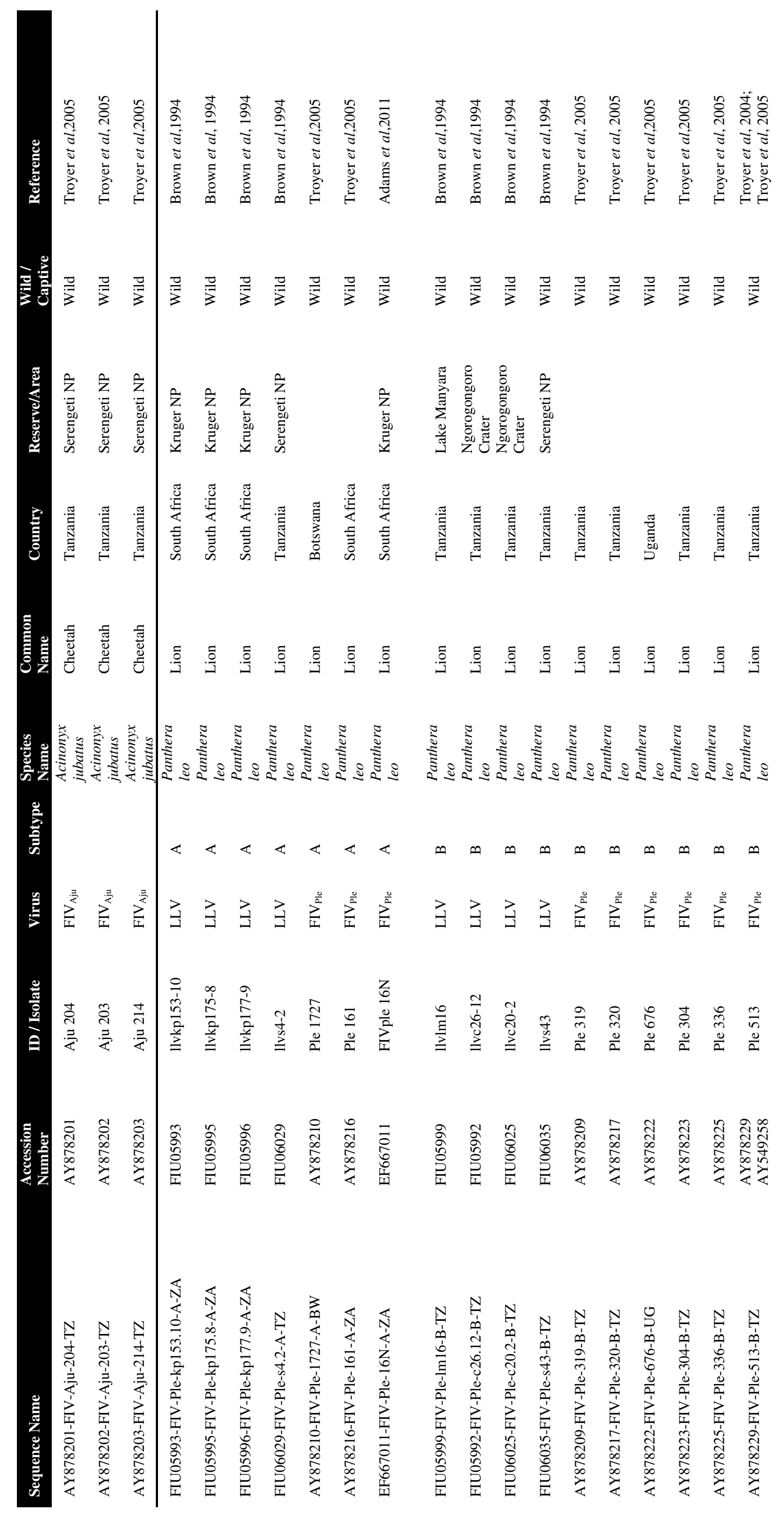




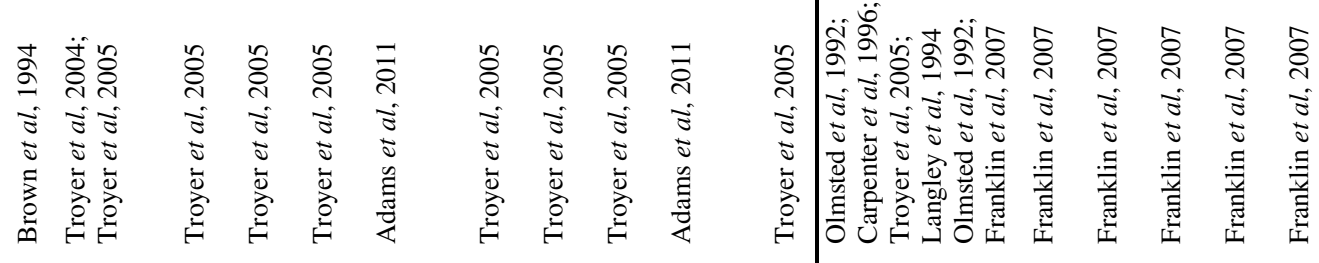

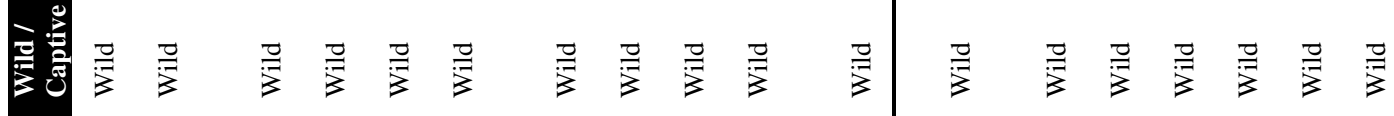

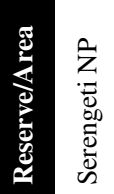

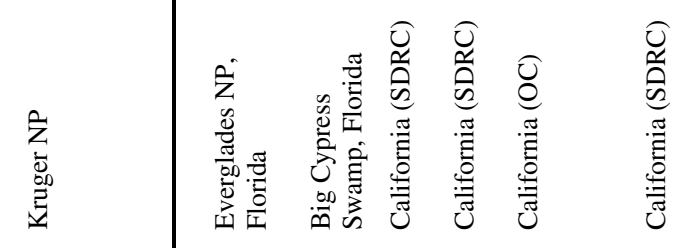

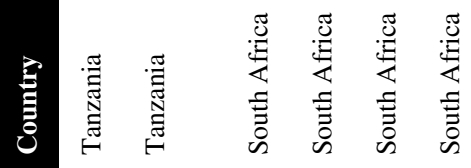

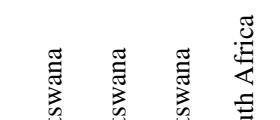

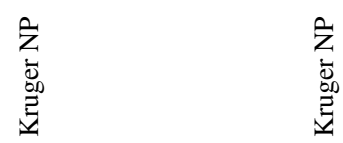

章

急

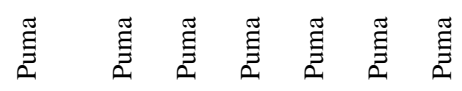

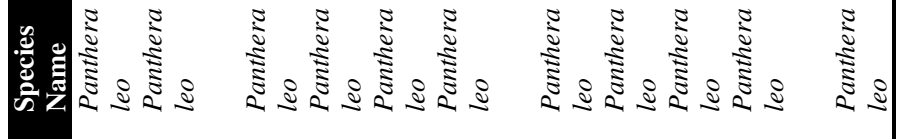

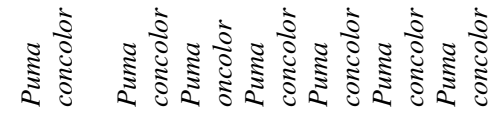

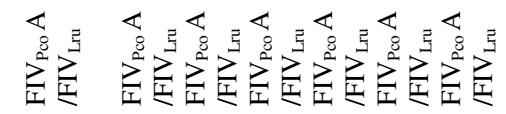

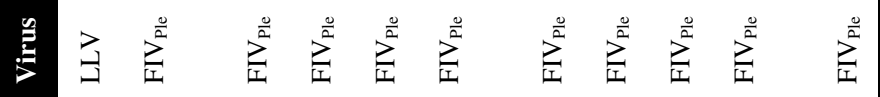

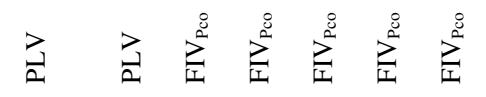

产

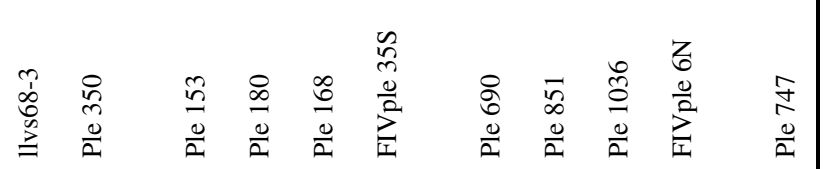

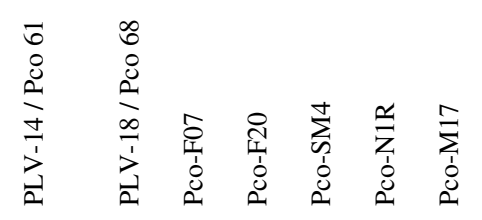

Oิ

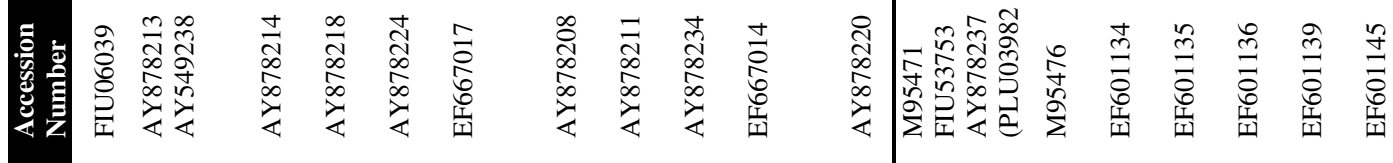




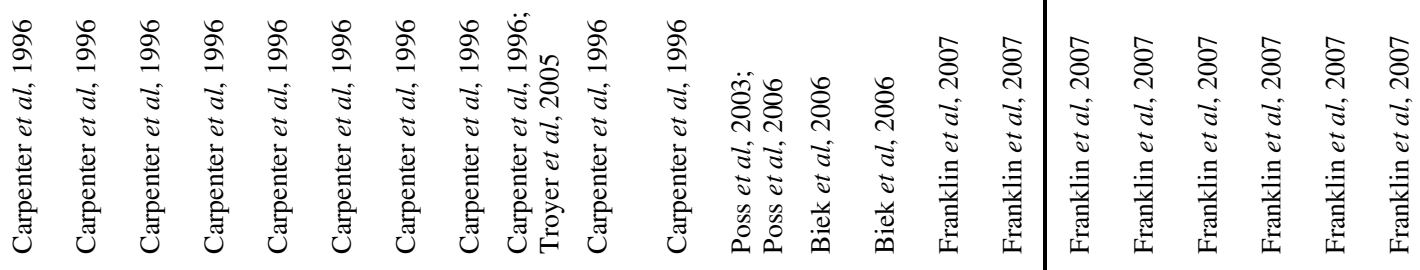

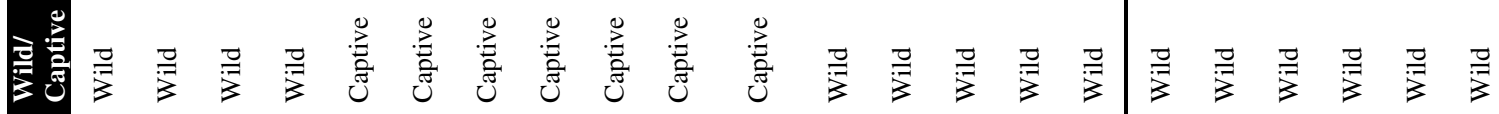

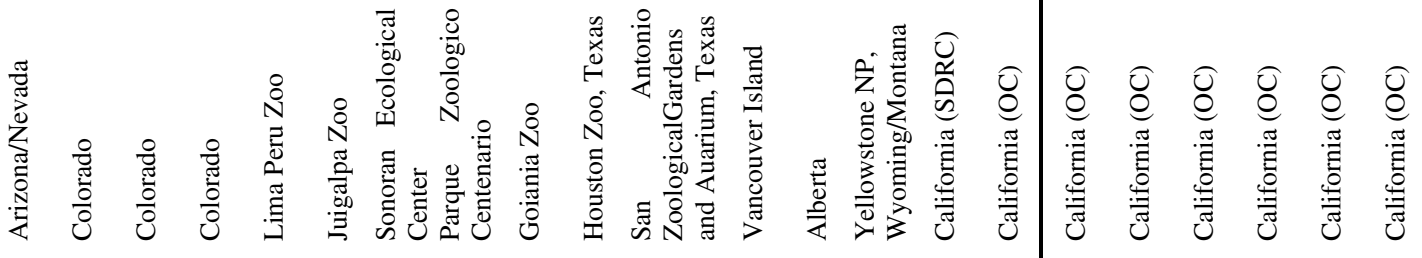

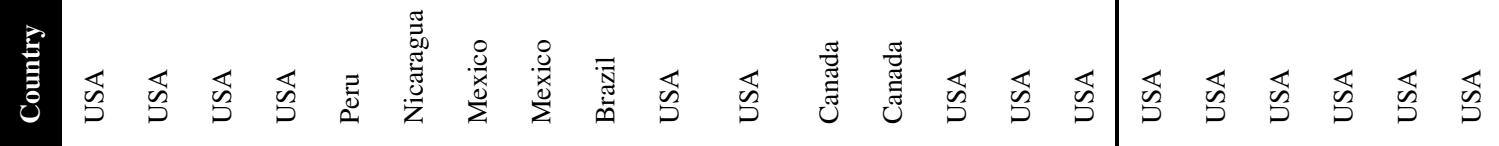

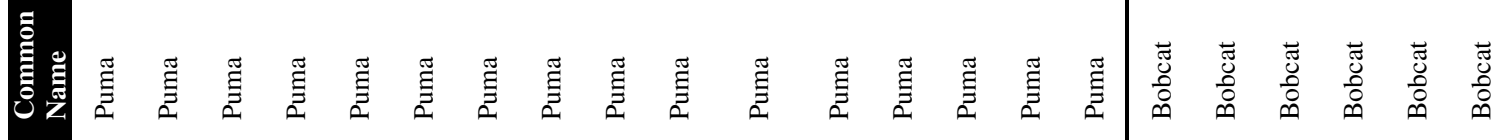

Whing

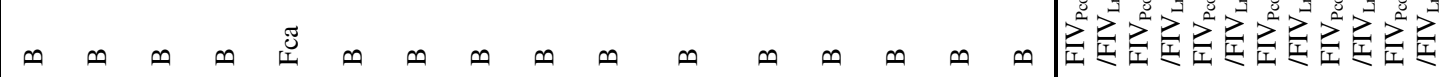

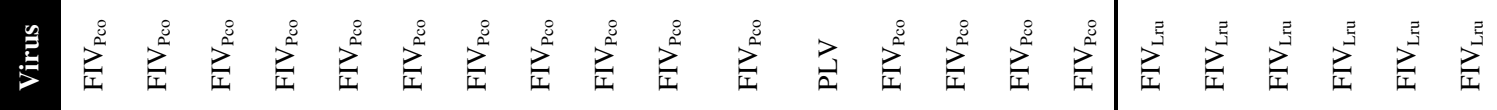

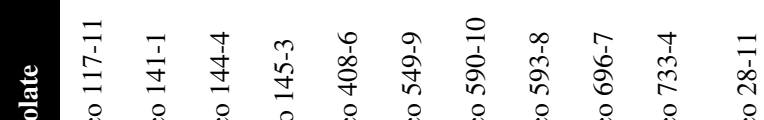

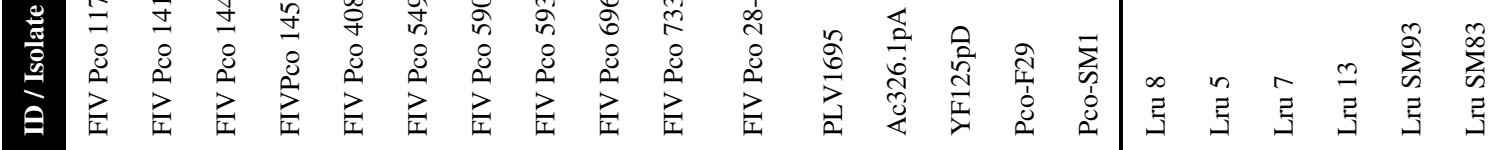

ठิ

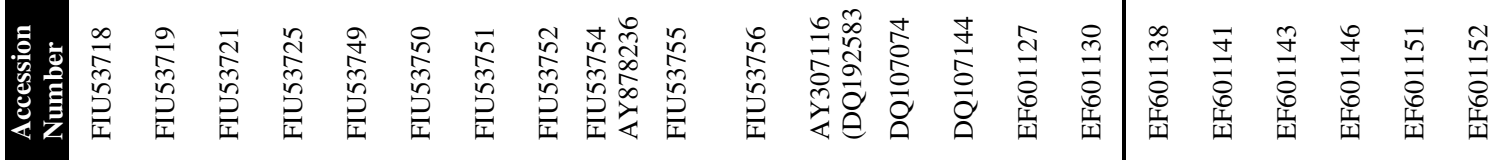

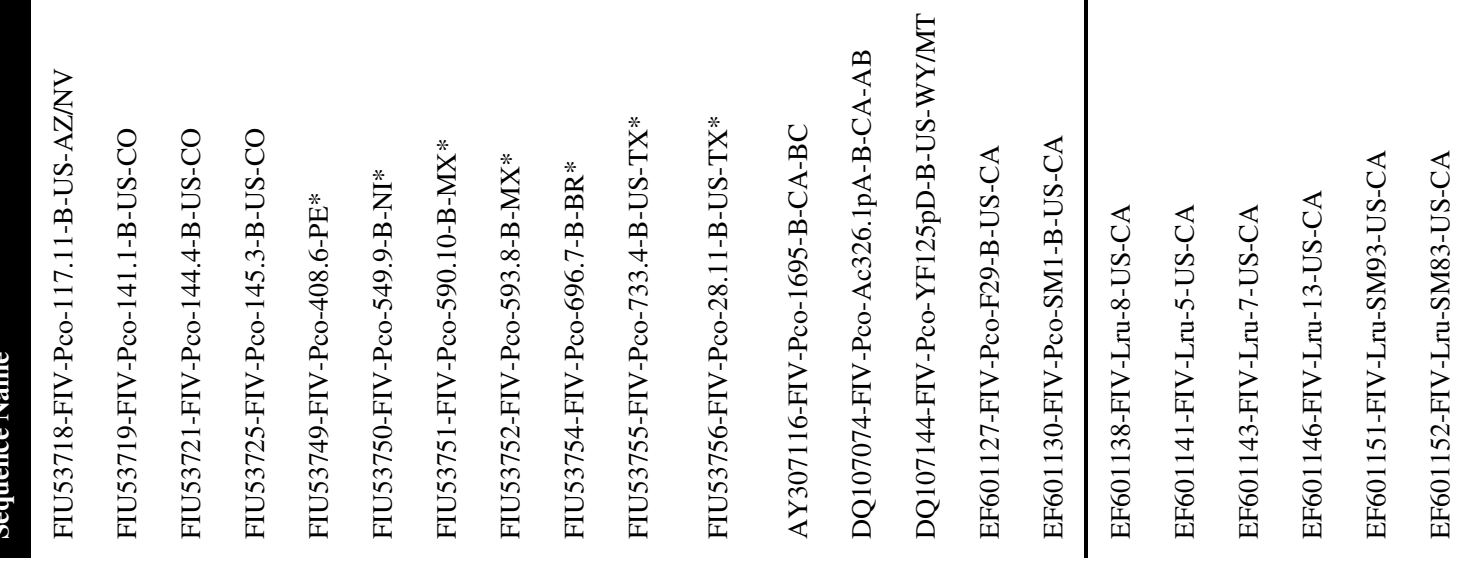

